\title{
Macroalgal metabolism and lateral carbon flows can create significant carbon sinks
}

\author{
Kenta Watanabe ${ }^{1}$, Goro Yoshida ${ }^{2}$, Masakazu Hori ${ }^{2}$, Yu Umezawa ${ }^{3}$, Hirotada Moki ${ }^{1}$, and Tomohiro Kuwae \\ ${ }^{1}$ Coastal and Estuarine Environment Research Group, Port and Airport Research Institute, \\ 3-1-1 Nagase, Yokosuka 239-0826, Japan \\ ${ }^{2}$ National Research Institute of Fisheries and Environment of Inland Sea, Japan Fisheries Research \\ and Education Agency, 2-17-5 Maruishi, Hatsukaichi 739-0452, Japan \\ ${ }^{3}$ Department of Environmental Science on Biosphere, Tokyo University of Agriculture and Technology, \\ 3-5-8 Saiwai-cho, Fuchu, Tokyo 183-8509, Japan
}

Correspondence: Kenta Watanabe (watanabe-ke@p.mpat.go.jp)

Received: 15 November 2019 - Discussion started: 19 November 2019

Revised: 24 March 2020 - Accepted: 7 April 2020 - Published: 5 May 2020

\begin{abstract}
Macroalgal beds have drawn attention as one of the vegetated coastal ecosystems that act as atmospheric $\mathrm{CO}_{2}$ sinks. Although macroalgal metabolism as well as inorganic and organic carbon flows are important pathways for $\mathrm{CO}_{2}$ uptake by macroalgal beds, the relationships between macroalgal metabolism and associated carbon flows are still poorly understood. In the present study, we investigated carbon flows, including air-water $\mathrm{CO}_{2}$ exchange and budgets of dissolved inorganic carbon, total alkalinity, and dissolved organic carbon (DOC), in a temperate macroalgal bed during the productive months of the year. To assess the key mechanisms responsible for atmospheric $\mathrm{CO}_{2}$ uptake by the macroalgal bed, we estimated macroalgal metabolism and lateral carbon flows (i.e., carbon exchanges between the macroalgal bed and the offshore area) by using field measurements of carbon species, a field-bag method, a degradation experiment, and mass-balance modeling in a temperate Sargassum bed over a diurnal cycle. Our results showed that macroalgal metabolism and lateral carbon flows driven by water exchange affected air-water $\mathrm{CO}_{2}$ exchange in the macroalgal bed and the surrounding waters. Macroalgal metabolism caused overlying waters to contain low concentrations of $\mathrm{CO}_{2}$ and high concentrations of DOC that were efficiently exported offshore from the macroalgal bed. These results indicate that the exported water can potentially lower $\mathrm{CO}_{2}$ concentrations in the offshore surface water and enhance atmospheric $\mathrm{CO}_{2}$ uptake. Furthermore, the Sargassum bed exported $6 \%-35 \%$ of the macroalgal net commu-
\end{abstract}

nity production (NCP; $302-1378 \mathrm{mmol} \mathrm{C} \mathrm{m}^{-2} \mathrm{~d}^{-1}$ ) as DOC to the offshore area. The results of degradation experiments showed that $56 \%-78 \%$ of macroalgal DOC was refractory DOC (RDOC) that persisted for $150 \mathrm{~d}$; thus, the Sargassum bed exported 5\%-20\% of the macroalgal NCP as RDOC. Our findings suggest that macroalgal beds in habitats associated with high water exchange rates can create significant $\mathrm{CO}_{2}$ sinks around them and export a substantial amount of DOC to offshore areas.

\section{Introduction}

Vegetated coastal ecosystems provide a variety of ecosystem functions that support diverse biological communities and biogeochemical processes. Recent recognition of the carbon sequestration function of these ecosystems has led to the development of blue carbon strategies for mitigating the adverse effects of global climate change via conservation and restoration of these ecosystems (Nellemann et al., 2009; Duarte et al., 2013; Macreadie et al., 2019).

Carbon flows that sequester atmospheric $\mathrm{CO}_{2}$ in marine ecosystems over timescales of at least several decades are crucial for the mitigation of climate change (McLeod et al., 2011; Macreadie et al., 2019). Organic carbon burial in sediments is one of the most important pathways for sequestering carbon for a long time (Nellemann et al., 2009; Miyajima et al., 2019). Evaluation of the carbon sequestration function 
of vegetated coastal ecosystems has thus far been focused on salt marshes, seagrasses, and mangroves, which develop their own organic-rich sediments (Macreadie et al., 2019). In contrast, beds of macroalgae have been assumed to have limited capacity to sequester carbon because they generally settle on hard strata such as rocks and artificial structures (KrauseJensen et al., 2018). Organic matter produced by macroalgae shows variable lability, but it is generally more labile than that produced by vascular plants (Trevathan-Tackett et al., 2015) and hence is more efficiently utilized by consumers and decomposers (Duarte, 1995). However, macroalgal beds are estimated to be the most extensive vegetated coastal habitats $\left(3.5 \times 10^{6} \mathrm{~km}^{2}\right)$ in the global ocean, and their global net primary production $\left(1521 \mathrm{TgC}^{-1}\right)$ is larger than that of other vegetated coastal habitats (Krause-Jensen and Duarte, 2016; Duarte, 2017; Raven, 2018). Macroalgal beds therefore have the potential to regulate carbon dynamics in coastal ecosystems.

Other processes in addition to organic carbon burial in on-site sediments must exist for macroalgae to contribute to atmospheric $\mathrm{CO}_{2}$ sequestration. Recent studies have proposed that a large fraction of macroalgal production is exported to other vegetated coastal ecosystems, shelves, and the deep sea, where organic carbon derived from macroalgae can be stored in sediments and the water column for a long time (Krause-Jensen and Duarte, 2016; Krause-Jensen et al., 2018; Queirós et al., 2019).

The export and persistence of macroalgal dissolved organic carbon (DOC) have been proposed to be principal processes of macroalgal carbon sequestration, but more empirical support is needed to quantify this carbon flow. Macroalgal beds export about $43 \%$ of their production as DOC and particulate organic carbon (POC) (Krause-Jensen and Duarte, 2016). A first-order estimate has suggested that $33 \%$ of the flux of DOC derived from macroalgae is exported to depths below the mixed layer, where it contributes to carbon sequestration (Bauer and Druffel, 1998; Krause-Jensen and Duarte, 2016). Because the proportion of exported carbon that persists for a long time is estimated to be higher in DOC (33\%) than in POC (15\%) (Krause-Jensen and Duarte, 2016), DOC production, export, and degradation are believed to be significant processes for carbon sequestration. Although the production of refractory DOC by macroalgae is one of the important factors that impact carbon sequestration, there are few relevant data (e.g., Wada et al., 2008; Wada and Hama, 2013). The long residence time of refractory DOC in the water column increases the probability that it reaches depths below the mixed layer.

Even though macroalgal beds perform a significant function by assimilating organic carbon, the chemical kinetics of the carbonate system in the water column could cause them to be net $\mathrm{CO}_{2}$ emitters via air-water $\mathrm{CO}_{2}$ exchange. The dissolved constituents of the carbonate system must therefore be assessed to quantify the effect of community metabolism on air-water $\mathrm{CO}_{2}$ exchange (Macreadie et al., 2019; Tokoro et al., 2019). The high rates of macroalgal photosynthesis and respiration change dissolved inorganic carbon (DIC) concentrations. Calcification and dissolution of associated organisms modify the total alkalinity (TAlk) and DIC. Physical parameters and the balance of the carbonate system decide the magnitude of the air-water $\mathrm{CO}_{2}$ exchange (Tokoro et al., 2019). Indeed, some previous studies have shown that macroalgal beds act as sinks for atmospheric $\mathrm{CO}_{2}$ (Delille et al., 2009; Ikawa and Oechel, 2015; Koweek et al., 2017) and contribute substantially to global carbon fluxes (Smith, 1981; Krause-Jensen and Duarte, 2016). Macroalgal metabolism regulates diurnal and temporal variations in carbonate chemistry and affects calcification by calcifiers in macroalgal beds (Middelboe and Hansen, 2007; Krause-Jensen et al., 2015, 2016; Duarte and Krause-Jensen, 2018; Wahl et al., 2018). However, there is limited field evidence for how the effects of macroalgal metabolism on the carbonate system extend to adjacent water bodies.

Despite the importance of dissolved carbon flows as $\mathrm{CO}_{2}$ sequestration pathways, little attention has been paid to assessing the related carbon budgets in macroalgal beds. In this study, we assessed carbon flows, including air-water $\mathrm{CO}_{2}$ exchange and changes of DIC, TAlk, and DOC, in a temperate macroalgal bed during productive periods (winter). To quantify macroalgal metabolism and dissolved carbon flows, we used a field-bag method, a degradation experiment, and mass-balance modeling. In the present study, we focused on Sargassum beds because they are one of the dominant macroalgal habitats in both temperate and tropical regions (e.g., Fulton et al., 2019; Yoshida et al., 2019). Our goals were to quantify the contribution of macroalgal beds to atmospheric $\mathrm{CO}_{2}$ uptake and to investigate the responsible mechanisms on a daily timescale.

\section{Materials and methods}

\subsection{Study site and sample collection}

This study was conducted in the coastal waters of Heigun Island $\left(33^{\circ} 46^{\prime} 1.7^{\prime \prime} \mathrm{N}, 132^{\circ} 15^{\prime} 24.3^{\prime \prime} \mathrm{E}\right)$ in the western Seto Inland Sea of Japan (Fig. 1). The macroalgal bed at the study site is dominated by Sargassum algae (Figs. S1 and S2 in the Supplement). The surface area of the macroalgal bed is $1.44 \mathrm{ha}$, and the macroalgal habitat is located at depths shallower than $5 \mathrm{~m}$ (mean depth $-2.0 \mathrm{~m}$ ). There is no significant freshwater input from the island. The study site is characterized by a relatively high tidal amplitude $(<4 \mathrm{~m})$, and it is adjacent to a deep strait $(\sim 60 \mathrm{~m})$.

Field surveys were conducted in February and March of 2019 in the macroalgal bed and the adjacent water bodies to take into account the temporal variations in biotic and abiotic conditions. Winter, including the months of February and March, is the most productive period of Sargassum algae around this study site (Yoshida et al., 2001). Surface 

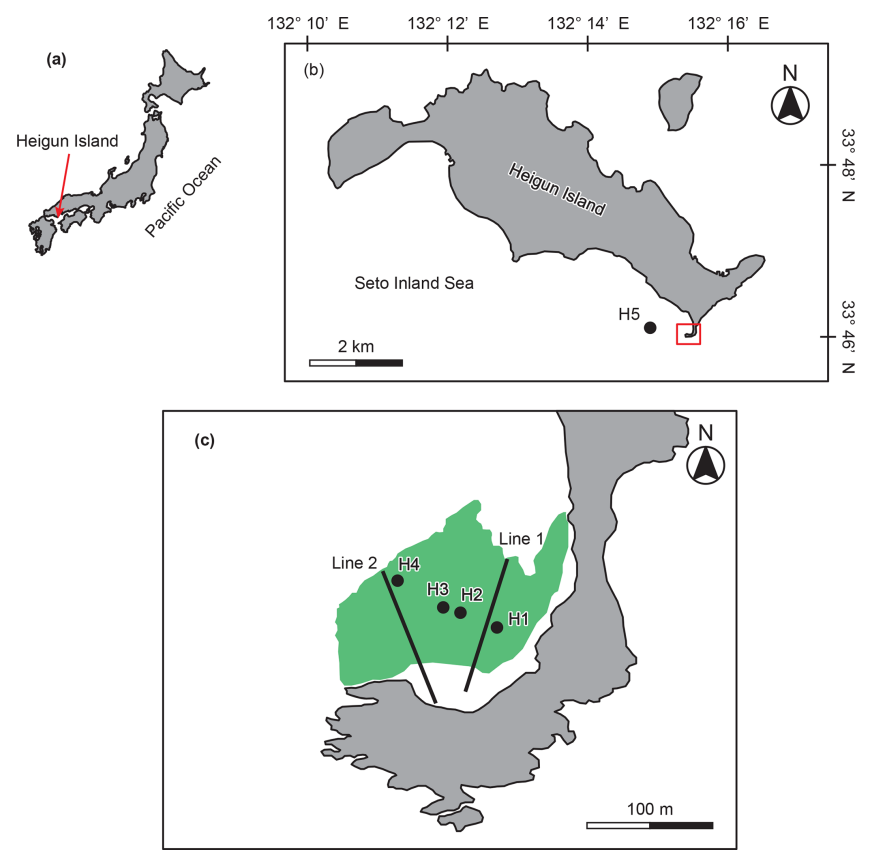

Figure 1. Maps of Heigun Island and the locations of sampling stations (H1-H5) and transect lines. Green shading indicates the area occupied by the macroalgal bed.

water samples for analyses of DIC, TAlk, and DOC were collected from a research vessel three times (10:00, 13:00, and 16:00 JST - Japan standard time) during the daytime (approximately from 7:00 to 17:00 JST) during both surveys at five stations (H1-H5; Fig. 1). Four stations (H1-H4) inside the macroalgal bed were chosen at equal intervals between the ends of the bed to assess average conditions. Station H5 was established at an offshore site. Samples for DIC and TAlk were dispensed into $250 \mathrm{~mL}$ Schott Duran bottles and preserved with mercuric chloride ( $200 \mu \mathrm{L}$ per bottle) to prevent DIC changes due to biological activity. Water samples for DOC analysis were filtered through $0.2 \mu \mathrm{m}$ polytetrafluoroethylene filters (DISMIC-25HP; Advantec, Durham, NC, USA) into precombusted $\left(450^{\circ} \mathrm{C}\right.$ for $\left.2 \mathrm{~h}\right) 50 \mathrm{~mL}$ glass vials and frozen at $-20^{\circ} \mathrm{C}$ until analysis. At each station, the salinity, temperature, and chlorophyll fluorescence of the surface water were recorded with a RINKO-Profiler (ASTD102, JFE Advantech, Nishinomiya, Japan).

Field-bag experiments (e.g., Towle and Pearse, 1973; Wada et al., 2007) were conducted to quantify the changes of DIC, TAlk, and DOC by macroalgae during $1 \mathrm{~d}$ in both February and March of 2019. We selected Sargassum horneri as the subject species because sufficient amounts of $S$. horneri were present in a zone suitable for the experiments. The entire thallus of an individual S. horneri was covered with a plastic bag containing ambient seawater collected in the macroalgal bed. The open end of the bag was tied at the algal stipe by scuba divers. Triplicate transparent and dark bags were set up to measure the changes of dissolved con- stituents due to macroalgal metabolism (Fig. S3). To assess the effect of phytoplankton, a set of transparent and dark bags were filled with ambient seawater that was collected in the macroalgal bed but contained no macroalgae. These bags served as control bags. Water samples from the bags were collected just after the start of the experiment and about $4 \mathrm{~h}$ later through a Tygon ${ }^{\circledR}$ tube by using a hand-held vacuum pump. The collected water samples were preserved with mercuric chloride for the carbonate chemistry analysis and filtered through the $0.2 \mu \mathrm{m}$ filters for the DOC analysis (vide supra). After the experiments, the volume of seawater and the wet weight of the macroalgae in each bag were measured. At the beginning and end of the experiments, the salinity, temperature, and chlorophyll fluorescence of the surface water were recorded with a RINKO-Profiler (ASTD102, JFE Advantech). Photosynthetic photon flux was measured with a photon flux sensor (DEFI-L, JFE Advantech) during the experiments.

The assessment of the biomass and species composition of the macroalgal bed that we studied was conducted in March 2019. Two $120 \mathrm{~m}$ transect lines were set from the shoreline to the edge of the macroalgal bed to document the biomass, coverage, and species composition of the macroalgae (Fig. 1). To assess the coverage and species composition, $1 \mathrm{~m} \times 1 \mathrm{~m}$ quadrats were located at $10 \mathrm{~m}$ intervals along each transect. Scuba divers quantified the apparent vegetation coverage and species composition in each quadrat. Five quadrats $(0.5 \mathrm{~m} \times 0.5 \mathrm{~m})$ were randomly located in the area dominated by Sargassum algae along each transect to quantify the wet weight biomass ( $\mathrm{g} \mathrm{WW}$ - grams wet weight) of the macroalgae. Scuba divers collected all macroalgae in each quadrat. The wet weight of the Sargassum algae and the other macroalgae were then measured immediately.

\subsection{Degradation experiment}

To quantify the degradation rates of macroalgal DOC due to microbial activity and to estimate the refractory fraction of that DOC, DOC samples for degradation experiments were obtained after the field-bag experiments. Water samples were collected from each transparent bag of macroalgae and control. The samples were filtered through precombusted $\left(450^{\circ} \mathrm{C}\right.$ for $\left.2 \mathrm{~h}\right)$ glass-fiber filters $(0.7 \mu \mathrm{m}$ pore size; GF/F, Whatman, Maidstone, Kent, UK) under reduced pressure. We assumed that GF/F filters would allow the passage of a significant fraction of free-living bacteria into the experimental samples (e.g., Wada et al., 2008; Bauer and Bianchi, 2011; Kubo et al., 2015).

The $40 \mathrm{~mL}$ filtrates were transferred into precombusted $\left(450{ }^{\circ} \mathrm{C}\right.$ for $\left.2 \mathrm{~h}\right) 100 \mathrm{~mL}$ glass vials sealed with rubber and aluminum caps. The $60 \mathrm{~mL}$ headspace in each glass bottle contained about $540 \mu \mathrm{mol}$ oxygen, which was sufficient to support the aerobic microbial degradation of DOC $(\sim$ $220 \mu \mathrm{mol})$ in each bottle if $1 \mathrm{~mol}$ of oxygen was consumed by the mineralization of $1 \mathrm{~mol}$ of DOC into $\mathrm{CO}_{2}$. The degra- 
dation experiments were conducted based on a total of six incubations $(0,3,10,30,90$, and $150 \mathrm{~d})$ per field survey. Triplicate bottles were used for each incubation. The experimental samples were stored at room temperature $\left(22^{\circ} \mathrm{C}\right)$ in total darkness until analysis. In the present study, we used room temperature for both samples to evaluate the quality of the organic matter. After incubation, the samples were filtered through $0.2 \mu \mathrm{m}$ polytetrafluoroethylene filters (DISMIC-25HP; Advantec) into precombusted $\left(450^{\circ} \mathrm{C}\right.$ for $2 \mathrm{~h}) 100 \mathrm{~mL}$ glass vials and frozen at $-20^{\circ} \mathrm{C}$ until analysis.

In this study, the concentration of refractory DOC (RDOC) was defined as the concentration of DOC remaining after $150 \mathrm{~d}$, and the concentration of DOC derived from macroalgae $\left(\mathrm{DOC}_{\mathrm{M}}\right)$ was equated to the difference between the DOC concentration in the macroalgae bag and the DOC concentration in the control bag $\left(\mathrm{DOC}_{\mathrm{C}}\right)$. Degradation rates $(k)$ were calculated by a first-order exponential decay model as follows:

$$
\operatorname{DOC}_{\mathrm{M}(t)}=\operatorname{DOC}_{\mathrm{M}(0)} \times e^{-k t} \text {, }
$$

where $\mathrm{DOC}_{\mathrm{M}(t)}$ is the amount of $\mathrm{DOC}_{\mathrm{M}}$ remaining at time $t$ $(\mathrm{d})$, and $k$ is the degradation rate $\left(\mathrm{d}^{-1}\right)$.

\subsection{Sample analyses}

The DIC concentration and TAlk were determined with a batch-sample analyzer (ATT-05 and ATT-15; Kimoto Electric, Osaka, Japan) according to Tokoro et al. (2014). The analytical precision of the system, based on the standard deviation of multiple reference replicates, was normally within $\pm 2 \mu \mathrm{mol} \mathrm{L}{ }^{-1}$ for DIC and TAlk.

DOC concentrations were measured at least in triplicate with a total organic carbon analyzer (TOC-L; Shimadzu, Kyoto, Japan) as non-purgeable organic carbon according to Ogawa et al. (1999). Potassium hydrogen phthalate (Wako Pure Industries, Osaka, Japan) adjusted to three concentrations $(83,166$, and $332 \mu \mathrm{M})$ was used as a standard for the measurement. The coefficient of variation of the analyses was less than $2 \%$.

\subsection{Metabolic parameters}

Net community production (NCP), gross community production (GCP), community respiration (R), community calcification (CC), and net DOC release (NDR) were determined from the changes in DIC, TAlk, and DOC of the field-bag experiments. These metabolic parameters were determined for both control and macroalgae as follows:

$$
\begin{gathered}
\text { Control NCP }\left(\mu \mathrm{molCL}^{-1} \mathrm{~h}^{-1}\right) \\
=-\frac{\Delta \mathrm{DIC}_{\mathrm{L}}-0.5 \times \Delta \mathrm{TAlk}_{\mathrm{L}}}{T},
\end{gathered}
$$

Control R $\left(\mu \mathrm{molCL}^{-1} \mathrm{~h}^{-1}\right)$

$$
=\frac{\Delta \mathrm{DIC}_{\mathrm{D}}-0.5 \times \Delta \mathrm{TAlk}_{\mathrm{D}}}{T}
$$

$$
\begin{aligned}
& \text { Control GCP }\left(\mu \mathrm{molCL} \mathrm{CL}^{-1} \mathrm{~h}^{-1}\right) \\
& =\text { Control NCP }+ \text { Control R, }
\end{aligned}
$$

ControlCC $\left(\mu \mathrm{molCL}^{-1} \mathrm{~h}^{-1}\right)=-\frac{0.5 \times \Delta \mathrm{TAlk}}{T}$,

Control NDR $\left(\mu \mathrm{molCL}{ }^{-1} \mathrm{~h}^{-1}\right)=\frac{\Delta \mathrm{DOC}}{T}$,

Macroalgal NCP $\left(\mu \mathrm{molCg} \mathrm{gW}^{-1} \mathrm{~h}^{-1}\right)$

$$
=\frac{V}{B} \times\left(-\frac{\Delta \mathrm{DIC}_{\mathrm{L}}-0.5 \times \Delta \mathrm{TAlk}_{\mathrm{L}}}{T}-\text { Control NCP }\right) \text {, }
$$

Macroalgal R $\left(\mu \mathrm{molCg} \mathrm{WW}{ }^{-1} \mathrm{~h}^{-1}\right)$

$$
=\frac{V}{B} \times\left(\frac{\Delta \mathrm{DIC}_{\mathrm{D}}-0.5 \times \Delta \mathrm{TAlk}_{\mathrm{D}}}{T}-\text { Control } \mathrm{R}\right),
$$

Macroalgal GCP $\left(\mu \operatorname{molCg~} \mathrm{WW}^{-1} \mathrm{~h}^{-1}\right)$

$=$ Macroalgal NCP + Macroalgal R ,

Macroalgal CC $\left(\mu \mathrm{molCg} \mathrm{WW}{ }^{-1} \mathrm{~h}^{-1}\right)$

$$
=\frac{V}{B} \times\left(-\frac{0.5 \times \Delta \mathrm{TAlk}}{T}-\text { Control CC }\right),
$$

Macroalgal NDR $\left(\mu \mathrm{molCg} \mathrm{WW}{ }^{-1} \mathrm{~h}^{-1}\right)$

$$
=\frac{V}{B} \times\left(\frac{\Delta \mathrm{DOC}}{T}-\text { Control NDR }\right) \text {. }
$$

In both the control and macroalgal field-bag experiments, $\triangle \mathrm{DIC}, \triangle \mathrm{TAlk}$, and $\triangle \mathrm{DOC}$ were equated to the final concentrations minus the initial concentrations. The subscripts $\mathrm{L}$ and $\mathrm{D}$ indicate transparent (i.e., light) and dark bags, respectively. The variables $V, B$, and $T$ are the volume of seawater $(\mathrm{L})$, the wet weight of the macroalgae ( $\mathrm{gWW})$, and the incubation time (h) in each bag, respectively. The CC and NDR rates were calculated for the daytime and nighttime separately by using the data from the light and dark experiments, respectively. The metabolic parameters were converted to daily areal rates $\left(\mathrm{mmol} \mathrm{Cm}^{-2} \mathrm{~d}^{-1}\right)$ by using the mean macroalgal biomass, the mean water depth, the lengths of the photoperiods, and the results of both daytime and night-time experiments. The photoperiod was defined as the time interval between sunrise and sunset; photoperiods were obtained from Automated Meteorological Data Acquisition System (AMeDAS) data provided by the Japan Meteorological Agency (available at https://www.jma.go.jp, last access: 24 March 2020).

\subsection{Air-water $\mathrm{CO}_{2}$ flux}

The air-water $\mathrm{CO}_{2}$ flux $\left(F \mathrm{CO}_{2}\right)$ was determined by using the bulk formula method. The equation for the method is as follows:

$F \mathrm{CO}_{2}=-K \times S \times\left(f \mathrm{CO}_{2 \text { water }}-f \mathrm{CO}_{2 \text { air }}\right)$, 
where $f \mathrm{CO}_{2}$ is fugacity. The gas transfer velocity $(K)$ was determined from empirical relationships between $K$ and the wind speed above the surface of the water (e.g., Wanninkhof, 1992; McGillis et al., 2001). $S$ is the $\mathrm{CO}_{2}$ solubility in the water. A positive $F \mathrm{CO}_{2}$ value indicates $\mathrm{CO}_{2}$ uptake from the air to the water. Here we used the following empirical equation to estimate $K$ (Wanninkhof, 1992):

$K=0.39 \times U_{10}^{2} \times\left(\frac{S c}{660}\right)^{-0.5}$,

where $U_{10}$ is the wind speed at a height of $10 \mathrm{~m}$ above the water surface. We determined $U_{10}$ by assuming that there was a logarithmic relationship between wind speed, height, and the roughness of the water surface (Kondo, 2000). Wind speed was obtained from AMeDAS data provided by the Japan Meteorological Agency and was measured about $10 \mathrm{~km}$ away at Agenosho (altitude: $6.5 \mathrm{~m}$ ) (available at https://www.jma.go. $\mathrm{jp})$. The Schmidt number $(S c)$ was determined from the water temperature and salinity of the water surface.

The solubility $(S)$ of $\mathrm{CO}_{2}$ is a function of water temperature and salinity (Weiss, 1974). $f \mathrm{CO}_{2}$ water and $f \mathrm{CO}_{2}$ air are the fugacities of $\mathrm{CO}_{2}$ in water and air, respectively. The values of $f \mathrm{CO}_{2}$ water were estimated with the CO2SYS program (Lewis and Wallace, 1998) and the TAlk and DIC of the water samples (Zeebe and Wolf-Gladrow, 2001). The average salinity and water temperature were used to calculate $f \mathrm{CO}_{2}$ water in each survey. We used the averaged $f \mathrm{CO}_{2}$ air $(410 \mu \mathrm{atm})$ measured with a $\mathrm{CO}_{2}$ analyzer (CO2-09; Kimoto Electric, Osaka, Japan).

\subsection{Mass-balance modeling}

We simulated the diurnal changes and budgets of the carbonate system and DOC in the macroalgal bed by using massbalance models (Fig. 2). The mass-balance models of the macroalgal bed simulated a hypothetical average macroalgal bed covering an area of $1 \mathrm{~m}^{2}$. The average depth of the hypothetical macroalgal bed was the same as that of the macroalgal bed at the study site $(2.0 \mathrm{~m})$, and the tide was simulated by changing the water height in synchrony with the observed tide. We used the average biomass of Sargassum algae obtained from the field survey in the mass-balance models. This modeling was conducted solely for the macroalgal bed, and the observed values of the offshore site (H5) were used as the boundary conditions for carbon inflowing into the macroalgal bed.

Time course changes in the concentrations of DIC, TAlk, and DOC $\left(\mu \mathrm{mol} \mathrm{L}^{-1}\right)$ in the macroalgal bed were calculated at hourly time intervals (Fig. 2). The duration of the simulation was $24 \mathrm{~h}$, beginning at sunrise of the survey day. Each concentration at time step $(t)$ was calculated from the concentration at time step $(t-1)$ as follows:

$$
\begin{aligned}
\mathrm{DIC}_{(t)} & =\left(\mathrm{DIC}_{(t-1)}-\mathrm{GCP}+\mathrm{R}-\mathrm{CC}+F \mathrm{CO}_{2}\right) \\
& \times\left(1-\mathrm{EX}_{(t)}\right)+\mathrm{DIC}_{\mathrm{O}} \times \mathrm{EX}_{(t)},
\end{aligned}
$$

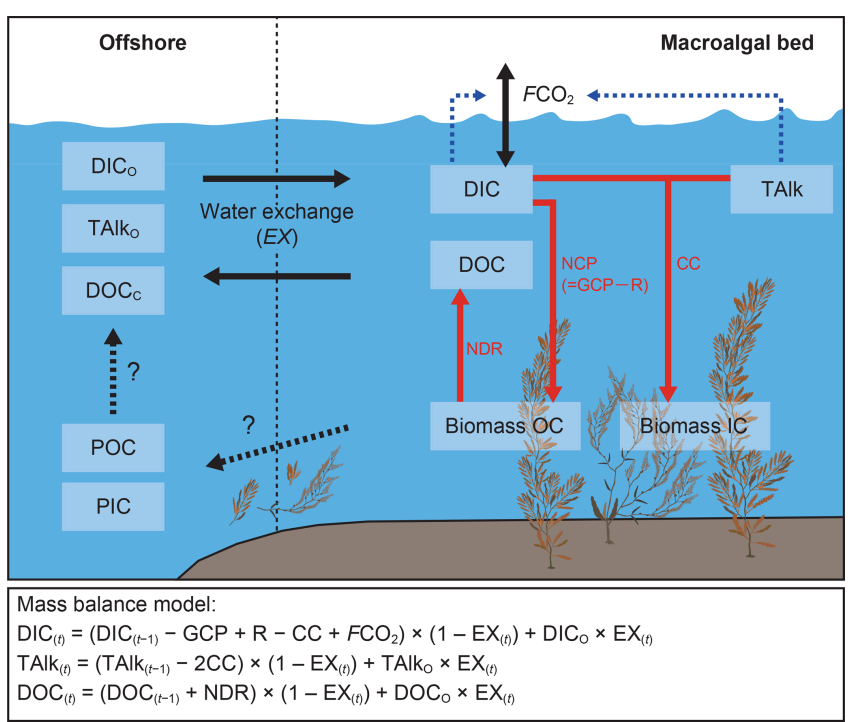

Figure 2. Schematic diagram of the different carbon pools and flows in and around macroalgal beds. Black arrows indicate carbon flows between macroalgal beds and the outside of the system, black dashed arrows with question marks denote carbon flows that were not evaluated in this study, and red arrows indicate effects of community metabolism on carbon pools in macroalgal beds. Blue dashed arrows indicate that dissolved inorganic carbon (DIC) and total alkalinity (TAlk) regulate air-water $\mathrm{CO}_{2}$ exchange fluxes $\left(\mathrm{FCO}_{2}\right)$. DIC concentrations in macroalgal beds are regulated by net community production (NCP), community calcification (CC), $\mathrm{FCO}_{2}$, and mixing with offshore DIC (DIC $\left.\mathrm{O}\right)$. NCP is calculated by subtracting community respiration $(\mathrm{R})$ from gross community production (GCP). TAlk in macroalgal beds is regulated by $\mathrm{CC}$ and mixing with offshore TAlk (TAlk $\mathrm{O}$ ). Dissolved organic carbon (DOC) concentrations in macroalgal beds are regulated by net DOC release (NDR) and mixing with offshore DOC $\left(\mathrm{DOC}_{\mathrm{O}}\right)$. Organic carbon (OC) and inorganic carbon (IC) of macroalgal biomass are produced by NCP and CC, respectively, and some of each is exported offshore in particulate form (POC and PIC, respectively). Mass-balance models simulated the diurnal changes and budgets of DIC, TAlk, and DOC in the macroalgal bed at hourly time steps $(t)$ in this study.

$$
\begin{aligned}
\operatorname{TAlk}_{(t)} & =\left(\operatorname{TAlk}_{(t-1)}-2 \mathrm{CC}\right) \\
& \times\left(1-\mathrm{EX}_{(t)}\right)+\mathrm{TAlk}_{\mathrm{O}} \times \mathrm{EX}_{(t)} \\
\operatorname{DOC}_{(t)} & =\left(\mathrm{DOC}_{(t-1)}+\mathrm{NDR}\right) \\
& \times\left(1-\mathrm{EX}_{(t)}\right)+\mathrm{DOC}_{\mathrm{O}} \times \mathrm{EX}_{(t)} .
\end{aligned}
$$

Metabolic parameters (GCP, R, CC, and NDR) were determined from changes in DIC, TAlk, and DOC measured in the field-bag experiments (Fig. 2 and Table S1 in the Supplement). These metabolic parameters were calculated as the sum of the contributions from both macroalgae and phytoplankton. The parameters $\mathrm{DIC}_{\mathrm{O}}$, $\mathrm{TAlk}_{\mathrm{O}}$, and $\mathrm{DOC}_{\mathrm{O}}$ in Eqs. (14)-(16) are the mean values of DIC, TAlk, and DOC, respectively, at the offshore station (H5), and the initial values in the simulation were equated to those values. Namely, 
$\mathrm{DIC}_{(0)}, \mathrm{TAlk}_{(0)}$, and DOC $(0)$ were equated to $\mathrm{DIC}_{\mathrm{O}}, \mathrm{TAlk}_{\mathrm{O}}$, and $\mathrm{DOC}_{\mathrm{O}}$, respectively. We assumed that there was no biogeochemical exchange between the bottom substrate and water. In the simulation, we assumed that the metabolic parameters (GCP, R, CC, and NDR) of S. horneri were applied to the entire macroalgal bed and used different metabolic parameters for day and night. EX $(0 \leq \mathrm{EX} \leq 1)$, the hourly water exchange rate, was defined as follows:

$\mathrm{EX}_{(t)}=\mathrm{EX}_{\text {tide }(t)}+\mathrm{EX}_{\mathrm{r}}$,

$\operatorname{EX}_{\text {tide }(t)}=\left\{\begin{array}{cc}\frac{H_{(t)}-H_{(t-1)}}{H_{(t)}} & \left(H_{(t)} \geq H_{(t-1)}\right) \\ 0 & \left(H_{(t)}<H_{(t-1)}\right)\end{array}\right.$.

$\mathrm{EX}_{\text {tide }}$ indicates the water exchange rate due to tidal change. $\mathrm{EX}_{\text {tide }}$ was estimated from the changes of water height $(H)$ and was positive during the flood tide and zero during the ebb tide. $\mathrm{EX}_{\mathrm{r}}$ was defined as the residual exchange rate due to factors other than tidal exchange (e.g., wind-driven water exchange and coastal currents). The value of $\mathrm{EX}_{\mathrm{r}}$ was chosen so as to minimize the root-mean-square error (RMSE) of the modeled values versus the observed values. RMSEs were calculated for the $z$ scores of DIC, TAlk, DOC, and $f \mathrm{CO}_{2}$, which were equated to the differences between the modeled values and the means of the observed values divided by the standard deviations of the observed values. The value of $\mathrm{EX}_{\mathrm{r}}$ that minimized the averaged RMSEs for these four parameters was determined for each survey. This model fitting was performed using the daytime data. The estimated $\mathrm{EX}_{\mathrm{r}}$ was applied throughout the diurnal cycle on the assumption that $\mathrm{EX}_{\mathrm{r}}$ was comparable during the day and night. We ran two different model scenarios, one with and the other without water exchange (i.e., EX).

The budgets of DIC, TAlk, and DOC were calculated as the net gain or loss of each constituent due to water exchange. The changes in $f \mathrm{CO}_{2}$, which were estimated by using chemical equilibrium relationships and the TAlk and DIC of the water samples (Lewis and Wallace, 1998; Zeebe and WolfGladrow, 2001), were used to calculate $F \mathrm{CO}_{2}$. The average salinity and water temperature were used to calculate $f \mathrm{CO}_{2}$ in each survey.

\subsection{Statistical analyses}

Statistical analyses were performed by using $\mathrm{R}$ statistical packages (R Core Team, 2019). We used Welch's two-sample $t$ test to determine whether there were differences in salinity, DIC, TAlk, $f \mathrm{CO}_{2}$, and DOC between the macroalgal bed and the offshore site and to detect the differences between the initial and final concentrations of DOC during degradation experiments.

\section{Results}

\subsection{Carbonate system and DOC in the macroalgal bed}

There were no differences in salinity and TAlk between the macroalgal bed $(n=12)$ and the offshore site $(n=3)$ in either February or March (Welch's two-sample $t$ test, $p>0.05$; Fig. 3 and Table S2). The DIC concentration was significantly lower in the macroalgal bed $\left(1964 \pm 22 \mu \mathrm{mol} \mathrm{L}^{-1}\right)$ than at the offshore site $\left(1991 \pm 1 \mu \mathrm{mol} \mathrm{L}^{-1}\right)$ in February $(p=0.002)$ (Fig. 3 and Table S2). In March, the variation in the DIC concentration was large $\left(1962 \pm 43 \mu \mathrm{mol} \mathrm{L}^{-1}\right)$ in the macroalgal bed but was also significantly lower than at the offshore site $\left(1992 \pm 1 \mu \mathrm{mol} \mathrm{L}^{-1} ; p=0.033\right)$. The $f \mathrm{CO}_{2}$ values were significantly lower in the macroalgal bed than at the offshore site in both February $(p=0.001)$ and March $(p=$ 0.025 ; Fig. 3 and Table S2). The $f \mathrm{CO}_{2}$ values in the macroalgal bed (February $-265 \pm 31 \mu \mathrm{atm}$; March $-272 \pm 49 \mu \mathrm{atm}$ ) and the offshore site (February - $305 \pm 3 \mu \mathrm{atm}$; March $309 \pm 1 \mu \mathrm{atm})$ were lower than $f \mathrm{CO}_{2}$ air $(410 \mu \mathrm{atm})$. On average, the DOC concentrations were higher in the macroalgal bed than at the offshore site, but the difference between them was significant only in March ( $p=0.010$; Fig. 3 and Table S2). $f \mathrm{CO}_{2}$ was strongly correlated with DIC in both February and March (Fig. 4). The homogeneous buffer factors $(\beta)$, which were equated to the slopes of log-log plots of $f \mathrm{CO}_{2}$ versus DIC, were 10.81 and 9.36 in February and March, respectively.

Community carbon metabolism was calculated from the field-bag experiments (Tables 1 and $\mathrm{S} 1$ ). The NCP of macroalgae was about 4 times higher in March $\left(1378 \mathrm{mmol} \mathrm{C} \mathrm{m}^{-2} \mathrm{~d}^{-1}\right)$ than in February $\left(302 \mathrm{mmol} \mathrm{C} \mathrm{m}^{-2} \mathrm{~d}^{-1}\right.$ ) (Table 1) and was considerably higher than that of phytoplankton $\left(\sim 22 \mathrm{mmol} \mathrm{C} \mathrm{m}^{-2} \mathrm{~d}^{-1}\right)$. The net community calcification (NCC) of macroalgae was positive during both months (11-21 $\left.\mathrm{mmol} \mathrm{C} \mathrm{m}^{-2} \mathrm{~d}^{-1}\right)$, but the average carbon fluxes due to NCC were 1-2 orders of magnitude lower than those associated with NCP. The net DOC release rates of macroalgae were 107 and $88 \mathrm{mmol} \mathrm{C} \mathrm{m}^{-2} \mathrm{~d}^{-1}$ in February and March, respectively. These values were equivalent to about $35 \%$ and $6 \%$ of the NCP in February and March, respectively.

\subsection{Biomass and species composition of macroalgae}

The macroalgal bed was dominated by Sargassum algae (Figs. 5, S1, and S2). The biomass of Sargassum algae (mean: $4693 \mathrm{~g} \mathrm{WW} \mathrm{m}^{-2}$ ) was higher than that of the other macroalgae (264 $\left.\mathrm{g} \mathrm{WW} \mathrm{m}^{-2}\right)$ (Fig. 5). The coverage of Sargassum algae $(\sim 80 \%)$ was also larger than that of the other macroalgae $(\sim 51 \%)$.

\subsection{Degradation of DOC}

DOC concentrations collected from macroalgae bags decreased with time in both experiments (Welch's two-sample 
February
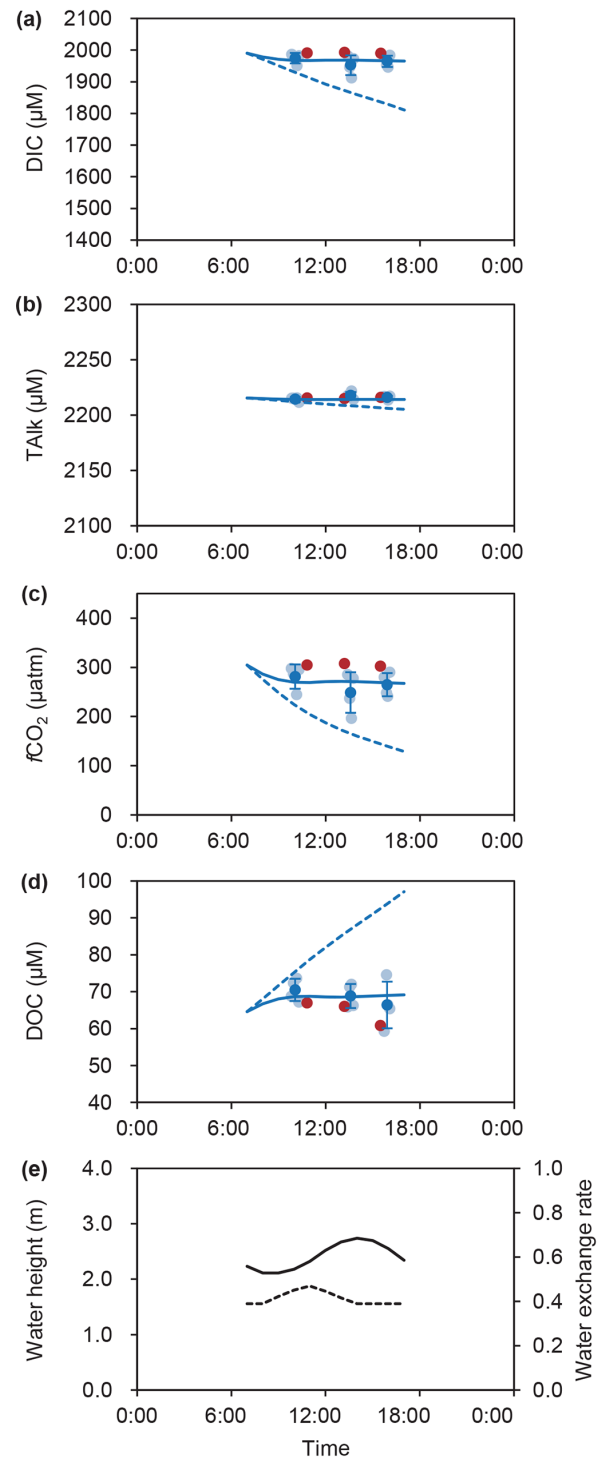

March
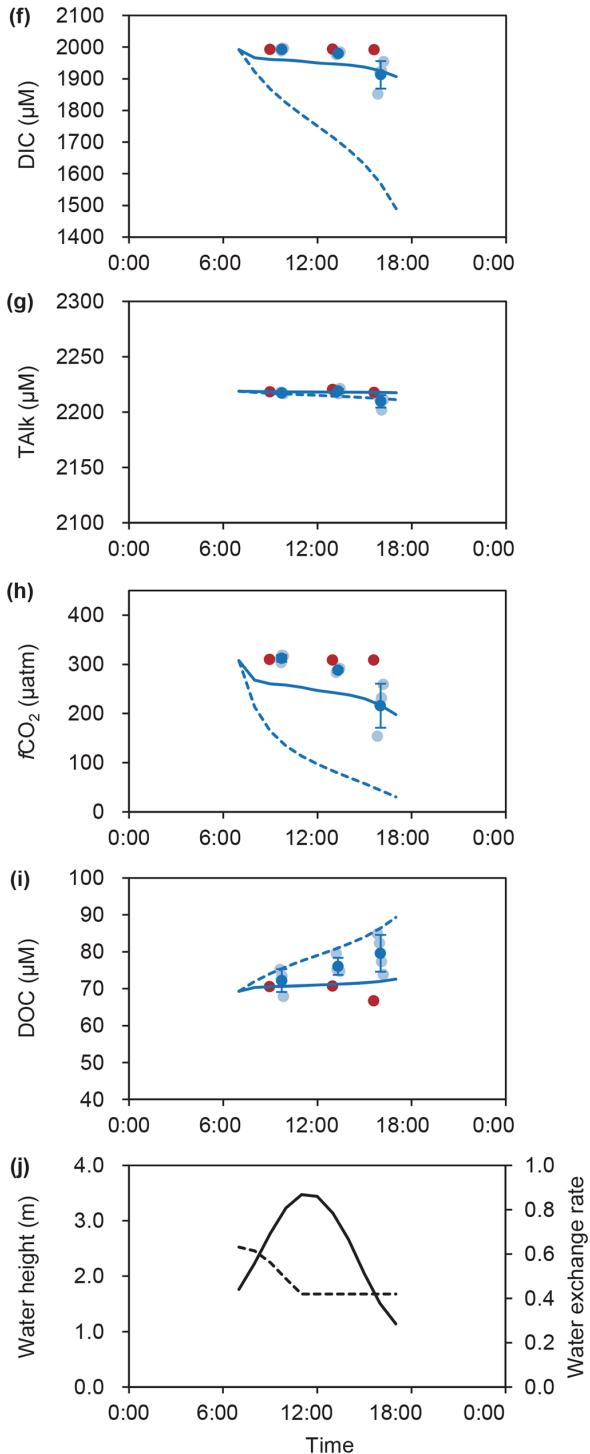

Figure 3. Temporal changes in dissolved inorganic carbon (DIC), total alkalinity (TAlk), fugacity of $\mathrm{CO}_{2}\left(f \mathrm{CO}_{2}\right)$, dissolved organic carbon (DOC), water height, and water exchange rate (EX) in February (a-e) and March (f-j). Modeled values of chemical parameters were estimated by using mass-balance models. Error bars show standard deviations. Blue dashed lines show the model results if the EX is zero. Details regarding observed values are provided in Table $\mathrm{S} 2$.

$t$ test, $p<0.05$; Fig. 6). In contrast, the stability of DOC concentrations collected from control bags during the experiments $(p>0.05)$ suggested that $\mathrm{DOC}_{\mathrm{M}}$ gradually decreased with time. Refractory $\mathrm{DOC}_{\mathrm{M}}\left(\mathrm{RDOC}_{\mathrm{M}}\right)$ concentrations were $56 \pm 4 \%$ and $78 \pm 27 \%$ of initial $\mathrm{DOC}_{M}$ concentrations in February and March, respectively (Fig. 6c). The degradation rate $(k)$ for $150 \mathrm{~d}$ incubations was higher in February $\left(0.0044 \mathrm{~d}^{-1}\right)$ than in March $\left(0.0021 \mathrm{~d}^{-1}\right)$.

\subsection{Carbon budgets estimated using mass-balance models}

The mass-balance models simulated the temporal changes of carbonate chemistry and DOC concentrations for the two model scenarios - that is, with and without considering water exchange (Fig. 3). The RMSEs of the $z$ scores of the bestfitting models considering water exchange (mean: February 
Table 1. Carbon metabolism, surface water temperature, photosynthetic photon flux, length of photoperiod, and chlorophyll fluorescence in February and March 2019. For macroalgae, means \pm standard deviations are shown. Average water depth and biomass in the bed were used for calculating metabolic rates.

\begin{tabular}{|c|c|c|c|}
\hline Variables & Units & Feb 2019 & Mar 2019 \\
\hline \multicolumn{4}{|l|}{ Macroalgae } \\
\hline Net community production & $\mathrm{mmol} \mathrm{Cm}^{-2} \mathrm{~d}^{-1}$ & $302 \pm 130$ & $1378 \pm 660$ \\
\hline Gross community production & $\operatorname{mmolC~m}{ }^{-2} \mathrm{~d}^{-1}$ & $572 \pm 129$ & $1637 \pm 646$ \\
\hline Community respiration & $\mathrm{mmolC} \mathrm{m}{ }^{-2} \mathrm{~d}^{-1}$ & $270 \pm 18$ & $259 \pm 133$ \\
\hline Net DOC release & $\operatorname{mmolC~m}{ }^{-2} \mathrm{~d}^{-1}$ & $107 \pm 36$ & $88 \pm 37$ \\
\hline Net community calcification & $\operatorname{mmolC~m}{ }^{-2} \mathrm{~d}^{-1}$ & $11 \pm 7$ & $21 \pm 23$ \\
\hline \multicolumn{4}{|l|}{ Control (phytoplankton) } \\
\hline Net community production & $\mathrm{mmolC} \mathrm{m}{ }^{-2} \mathrm{~d}^{-1}$ & 7 & 22 \\
\hline Gross community production & $\mathrm{mmol} \mathrm{C} \mathrm{m}-2 \mathrm{~d}^{-1}$ & 22 & 4 \\
\hline Community respiration & $\operatorname{mmolC~m}{ }^{-2} \mathrm{~d}^{-1}$ & 15 & -18 \\
\hline Net DOC release & $\mathrm{mmolC} \mathrm{m}^{-2} \mathrm{~d}^{-1}$ & 20 & 11 \\
\hline Net community calcification & $\mathrm{mmolC} \mathrm{m}{ }^{-2} \mathrm{~d}^{-1}$ & 3 & -12 \\
\hline Surface water temperature & ${ }^{\circ} \mathrm{C}$ & $12.0 \pm 0.2$ & $12.4 \pm 0.1$ \\
\hline Photosynthetic photon flux & $\mu \mathrm{mol} \mathrm{m}{ }^{-2} \mathrm{~s}^{-1}$ & $674 \pm 595$ & $1311 \pm 202$ \\
\hline Length of photoperiod & $\mathrm{h}$ & 11 & 12.5 \\
\hline Chlorophyll $a$ concentration & $\mu g \mathrm{~L}^{-1}$ & 0.3 & 0.8 \\
\hline
\end{tabular}

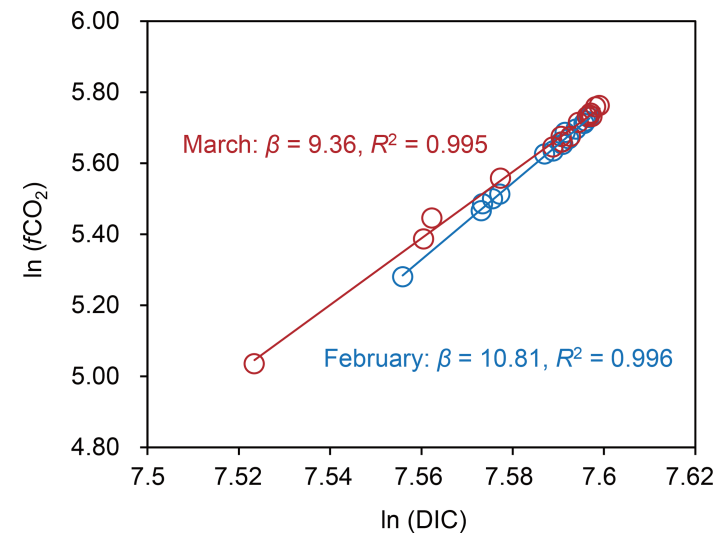

Figure 4. Plots of fugacity of $\mathrm{CO}_{2}\left(f \mathrm{CO}_{2}\right)$ versus dissolved inorganic carbon (DIC) and regression lines used to determine the homogeneous buffer factors $(\beta)$ as slopes.

- 0.56; March - 0.91) were lower than those assuming that water exchange was zero (mean: February - 3.77; March 3.10; Table 2). The fitted model that took into consideration EX improved the RMSEs of the $z$ scores of all parameters in February. In March, the RMSEs of the $z$ scores of DIC and $f \mathrm{CO}_{2}$ were improved by the model fitting, but those of DOC and TAlk showed little or no improvement (Table 2). The estimated $\mathrm{EX}_{\mathrm{r}}$ values were $39 \%$ and $42 \%$ in February and March, respectively (Table 3 ). The $\mathrm{EX}_{\mathrm{r}}$ rates were the main components of the hourly water exchange rates (the sums of $\mathrm{EX}_{\text {tide }}$ and $\mathrm{EX}_{\mathrm{r}}$ ), which were estimated to be $39 \%-52 \%$ and
$42 \%-68 \%$ in February and March, respectively (Fig. 3 and Table 3).

DIC concentrations were decreased in the daytime by primary production (Fig. 3a, f). TAlk values in the macroalgal bed were stable and very similar to the TAlk values of the offshore seawater (Fig. 3b, g). The $f \mathrm{CO}_{2}$ decreased during the daytime because of the concurrent decrease in the DIC concentration (Fig. 3c, h). DOC concentrations in the macroalgal bed exceeded those at the offshore site during the daytime (Fig. 3d, i).

DOC was exported offshore from the macroalgal bed (Fig. 7). The areal effluxes of DOC (February $125 \mathrm{mmol} \mathrm{C} \mathrm{m}^{-2} \mathrm{~d}^{-1}$; March $-96 \mathrm{mmol} \mathrm{C} \mathrm{m}^{-2} \mathrm{~d}^{-1}$ ) were similar to the NDRs. The export fluxes of $\mathrm{RDOC}_{\mathrm{M}}$ were estimated to be 59 and $67 \mathrm{mmol} \mathrm{C} \mathrm{m}^{-2} \mathrm{~d}^{-1}$ in February and March, respectively (Fig. 7). DIC budgets driven by water exchange indicated a net input of DIC from offshore to the macroalgal bed (Fig. 7 and Table 3). The areal influxes of DIC were 323 and $1386 \mathrm{mmol} \mathrm{C} \mathrm{m}^{-2} \mathrm{~d}^{-1}$ in February and March, respectively. These fluxes were almost equivalent to the sum of NCP, NCC, and $F \mathrm{CO}_{2}$ in the macroalgal bed (Fig. 7). The $\mathrm{FCO}_{2}$ values showed that both the macroalgal bed and the offshore site took up atmospheric $\mathrm{CO}_{2}$ during these study periods. $F \mathrm{CO}_{2}$ values were higher in the macroalgal bed than offshore during both periods (Fig. 7 and Table 3). 

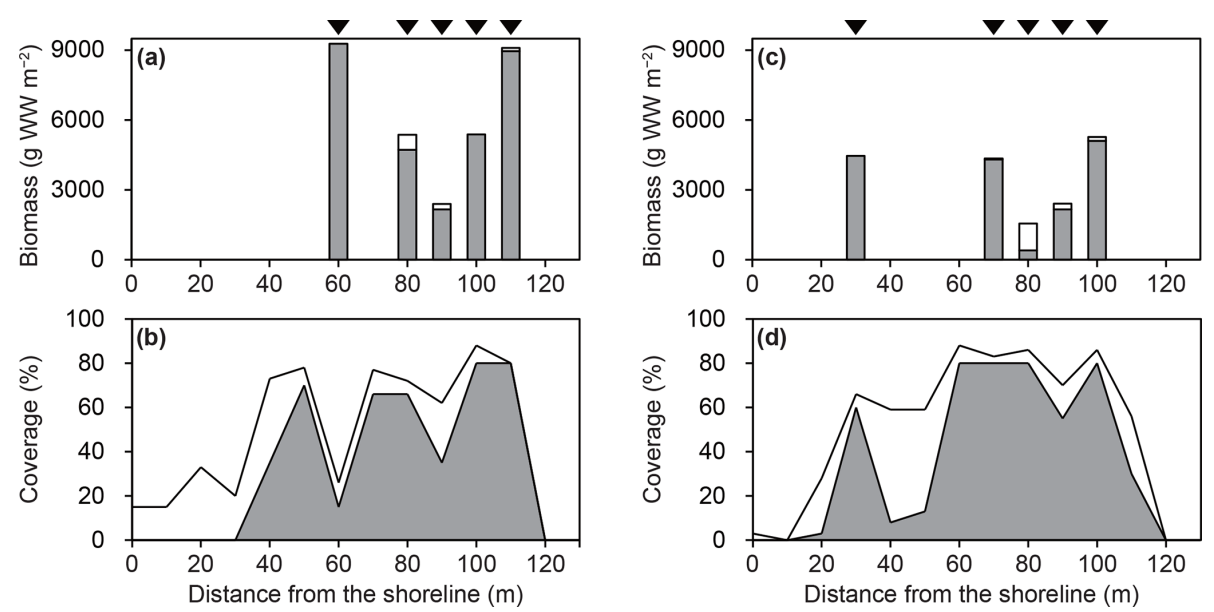

Figure 5. Biomass and coverage of macroalgae along transect line 1 (a, b) and line 2 (c, d) in March 2019. Grey and white shading indicate Sargassum algae and other macroalgae, respectively. Black arrows indicate sampling locations for macroalgal biomass.

Table 2. Root-mean-square errors (RMSEs) for best-fitting models and models assuming that water exchange rate (EX) was zero. RMSEs were calculated for the $z$ scores of DIC, TAlk, DOC, and $f \mathrm{CO}_{2}$ values, which were differences from the mean observed values divided by the standard deviations. The best-fitting model that minimized the averaged RMSEs for these four parameters was determined for each survey.

\begin{tabular}{lrr|rr}
\hline Variables & \multicolumn{2}{c|}{ Feb 2019 } & \multicolumn{2}{c}{ Mar 2019 } \\
\cline { 2 - 5 } & Best-fitting model & Model without EX & Best-fitting model & Model without EX \\
\hline DIC & 0.41 & 4.26 & 0.69 & 6.64 \\
TAlk & 0.99 & 3.52 & 0.96 & 0.62 \\
DOC & 0.41 & 4.46 & 1.07 & 1.04 \\
$f \mathrm{CO}_{2}$ & 0.44 & 2.85 & 0.91 & 4.10 \\
Mean & 0.56 & 3.77 & 0.91 & 3.10 \\
\hline
\end{tabular}

\section{Discussion}

\subsection{Refractory DOC release by macroalgae}

Our results showed that the Sargassum bed released a large amount of DOC (Fig. 7). Most of the released DOC was exported out of the macroalgal bed via water exchange during the day. The DOC release rates of S. horneri (18.7-22.8 $\mu \mathrm{mol} \mathrm{Cg} \mathrm{WW}^{-1} \mathrm{~d}^{-1}$; Table S1) were within the range of those reported for Ecklonia kelp (1.5-

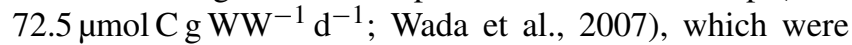
calculated by assuming that water content was $85 \%$ of wet weight (Watanabe et al., unpublished data). The fact that Wada et al. (2007) collected data over an entire year, whereas our data were collected during only the most productive 2 months of the year, accounts for the difference in the variations in DOC release rates. Previous studies have found that a substantial portion of production is released as DOC by kelps (18\%-62\%; Abdullah and Fredriksen, 2004; Wada et al., 2007). Our results showed that Sargassum algae sometimes release a similar percentage of production as DOC (February $-35 \%$; March $-6 \%$ ), and the percentages were very different between the 2 months, despite the similarity of the DOC release rates (Fig. 7). DOC release rates by kelps have been shown to be correlated with irradiance, but irradiance explained only $13 \%$ of the variation in the DOC release rates (Reed et al., 2015). Time lags between lightstimulated carbon assimilation and DOC release may explain some of the variation between irradiance and DOC release. High-frequency time-series measurements may help to explain the daily variations in macroalgal carbon metabolism. In this study, the reproducibility of the DOC mass-balance model (i.e., the improvement of RMSEs) differed between the February and March data sets (Fig. 3 and Table 2). Temporal and interspecific variations in DOC release rates may have caused this difference.

Refractory organic carbon acts as a carbon reservoir in seawater (Hansell and Carlson, 2014) and is considered to be one of the important contributors to carbon sequestration by coastal macrophytes (Maher and Eyre, 2010; Watanabe and Kuwae, 2015; Krause-Jensen and Duarte, 2016; Duarte and Krause-Jensen, 2017). Our results show that the Sargassum bed exported $5 \%-20 \%$ of the macroalgal NCP as RDOC that persisted for $150 \mathrm{~d}$ (Fig. 7). The fact that the degradation rates of macroalgal DOC are lower than those of DOC released by phytoplankton ( $k$ values, $>0.025 \mathrm{~d}^{-1}$; Hama et al., 
Table 3. Water exchange rates $\left(\mathrm{EX}_{\mathrm{r}}\right.$ and $\left.\mathrm{EX}_{\mathrm{tide}}\right), \mathrm{FCO}_{2}$, DIC exchange, and DOC exchange, which were estimated by using mass-balance models. Carbon fluxes were calculated as millimoles per square meter of the surface area of the algal bed per day.

\begin{tabular}{llrr}
\hline Variables & Units & Feb 2019 & Mar 2019 \\
\hline EX $_{\mathrm{r}}$ & $\% \mathrm{~h}^{-1}$ & 39 & 42 \\
$\mathrm{EX}_{\text {tide }}$ & $\% \mathrm{~h}^{-1}$ & $0-13$ & $0-26$ \\
$\mathrm{FCO}_{2}$ in macroalgal bed & $\mathrm{mmol} \mathrm{C} \mathrm{m}^{-2} \mathrm{~d}^{-1}$ & 10.3 & 1.8 \\
$F \mathrm{CO}_{2}$ offshore & $\mathrm{mmol} \mathrm{C} \mathrm{m}^{-2} \mathrm{~d}^{-1}$ & 9.2 & 1.2 \\
DIC exchange & $\mathrm{mmol} \mathrm{C} \mathrm{m}^{-2} \mathrm{~d}^{-1}$ & 323 & 1386 \\
DOC exchange & $\mathrm{mmol} \mathrm{C} \mathrm{m}^{-2} \mathrm{~d}^{-1}$ & -125 & -96 \\
\hline
\end{tabular}

2004; Kirchman et al., 1991) implies that macroalgal DOC is more biologically recalcitrant than DOC produced by phytoplankton (Wada et al., 2008). Previous studies have suggested that macroalgae produce phenolic compounds such as phlorotannin that are biologically recalcitrant (Swanson and Druehl, 2002; Wada and Hama, 2013; Powers et al., 2019). A thermogravimetric approach has also shown that macroalgal thalli contain refractory compounds (Trevathan-Tackett et al., 2015), some of which are released as the plant grows. These findings indicate that macroalgae release chemically recalcitrant DOC for decomposers.

Wada et al. (2008) have estimated the turnover times of the DOC released by Ecklonia kelp, the reciprocals of the degradation rates $(k)$, to be $24-172 \mathrm{~d}$ (i.e., $k$ values of $0.0058-0.0407 \mathrm{~d}^{-1}$ ) during $30 \mathrm{~d}$ incubations. In the present study, the turnover times of DOC released by $S$. horneri were calculated to be $111-238 \mathrm{~d}$ (i.e., $k$ values for $30 \mathrm{~d}$ incubations of $0.0042-0.0090 \mathrm{~d}^{-1}$ ), longer than the turnover times of Ecklonia kelp. These findings indicate that the recalcitrance of macroalgal DOC is variable and depends on the species and environmental conditions. The production of recalcitrant macroalgae compounds such as phlorotannins varies among seasons, growth phases, and species (Steinberg, 1989; Kamiya et al., 2010), and these variations may regulate seasonal and interspecific variations in the biological recalcitrance of macroalgal DOC. Furthermore, degradation rates for $150 \mathrm{~d}$ incubations $\left(0.0021-0.0044 \mathrm{~d}^{-1}\right.$; Fig. 6) were slower than those for first $30 \mathrm{~d}$ incubations, indicating that relatively short-duration degradation experiments may underestimate the long-term persistence of OC (e.g., TrevathanTackett et al., 2020).

The microbial degradation of DOC is also affected by temperature, and high temperature stimulates DOC degradation (e.g., Chen and Wangersky, 1996; Lønborg and ÁlvarezSalgado, 2012). In this study, the microbial degradation rates of DOC were potentially overestimated compared to in situ conditions because the incubation temperature for the degradation experiments $\left(22^{\circ} \mathrm{C}\right)$ was higher than the in situ temperature $\left(\sim 13^{\circ} \mathrm{C}\right.$; Table 1$)$. The difference in the initial $\mathrm{DOC}_{\mathrm{M}}$ concentrations in the macroalgae bags between February and March may have been caused by the differences in the biomass of macroalgae and volume of water in the experimental bags (Fig. 6a, b). Variations in DOC concentrations may affect degradation rates via resource limitation of microbial activity (e.g., Arrieta et al., 2015). Understanding of the fate of macroalgal DOC would be enhanced by the assessment of the physical and biochemical factors that regulate microbial degradation of DOC. The rates of DOC degradation processes, which were not measured in this study (e.g., photochemical degradation), might also be important in driving macroalgal DOC degradation (Wada et al., 2015).

Ogawa et al. (2001) have shown that marine bacteria take up labile organic matter $(\mathrm{OM})$ such as glucose and convert it into refractory OM. Some of the macroalgal DOC may be converted to refractory $\mathrm{OC}$ by microbes and persist in water for a long time. Carbon flows through the microbial loop should be assessed as one of the fates of OM derived from macroalgal beds.

\section{2 $\mathrm{CO}_{2}$ uptake and DIC budgets in the macroalgal bed}

Atmospheric $\mathrm{CO}_{2}$ uptake was affected by community metabolism and water exchange, which regulated the carbon budget in the Sargassum algae-dominated macroalgal bed. Positive NCP values showed that the macroalgal bed acted as an autotrophic system during the study periods. Macroalgal DIC uptake (i.e., NCP) accounted for $>97 \%$ of total NCP in this system (Table 1); the rest was attributable to planktonic NCP. Biological uptake of DIC promoted atmospheric $\mathrm{CO}_{2}$ uptake by contributing to the decrease in DIC concentrations and $f \mathrm{CO}_{2}$ during the day inside the macroalgal bed (Figs. 3 and 7).

Previous studies have shown that macroalgal primary production reduces DIC and $\mathrm{CO}_{2}$ concentrations. For example, DIC uptake by kelp reduces $f \mathrm{CO}_{2}$ and thereby contributes to the uptake of atmospheric $\mathrm{CO}_{2}$ inside kelp beds (Delille et al., 2000, 2009; Koweek et al., 2017; Pfister et al., 2019). The aquaculture of macroalgal species such as the kelp Laminaria japonica and the red algae Gracilaria lemaneiformis has also been shown to result in annual net uptake of $\mathrm{CO}_{2}$ because of active photosynthesis by the macroalgae (Jiang et al., 2013). In contrast, knowledge about in situ carbonate chemistry in beds of Sargassum algae is limited (e.g., Tokoro et al., 2019). 

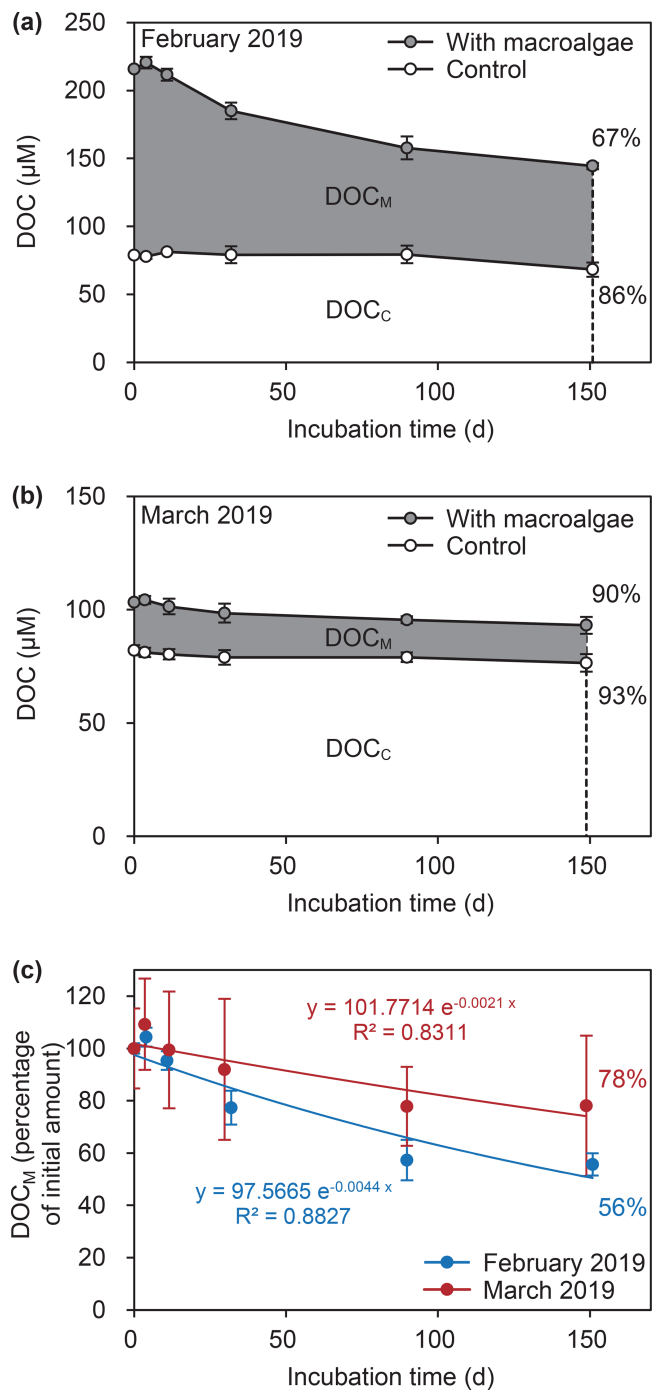

Figure 6. Time course of dissolved organic carbon (DOC) concentrations during the degradation experiments in (a) February and (b) March and (c) percentage of DOC derived from macroalgae $\left(\mathrm{DOC}_{\mathrm{M}}\right)$ during both experiments. Shading indicates the concentration of $\mathrm{DOC}_{\mathrm{M}}$, which was equated to the difference between the DOC concentration in the macroalgae bag and the DOC concentration in the control bag $\left(\mathrm{DOC}_{\mathrm{C}}\right)$. Percentages in panels (a) and (b) are averaged final percentages of DOC remaining in each treatment after $150 \mathrm{~d}$.

The present study, however, has shown that a bed of Sargassum algae takes up atmospheric $\mathrm{CO}_{2}$ over a diurnal cycle during productive periods of the year.

Our results showed that metabolism and water exchange regulated the diurnal variations in DIC and $f \mathrm{CO}_{2}$ in the macroalgal bed. Our mass-balance model analyses suggested that the high rate of water inflow from the outside the bed strongly affected DIC concentrations and $f \mathrm{CO}_{2}$ in the macroalgal bed (Fig. 3a, f). The decrease in the DIC concentration of the macroalgal bed was moderated by water ex-
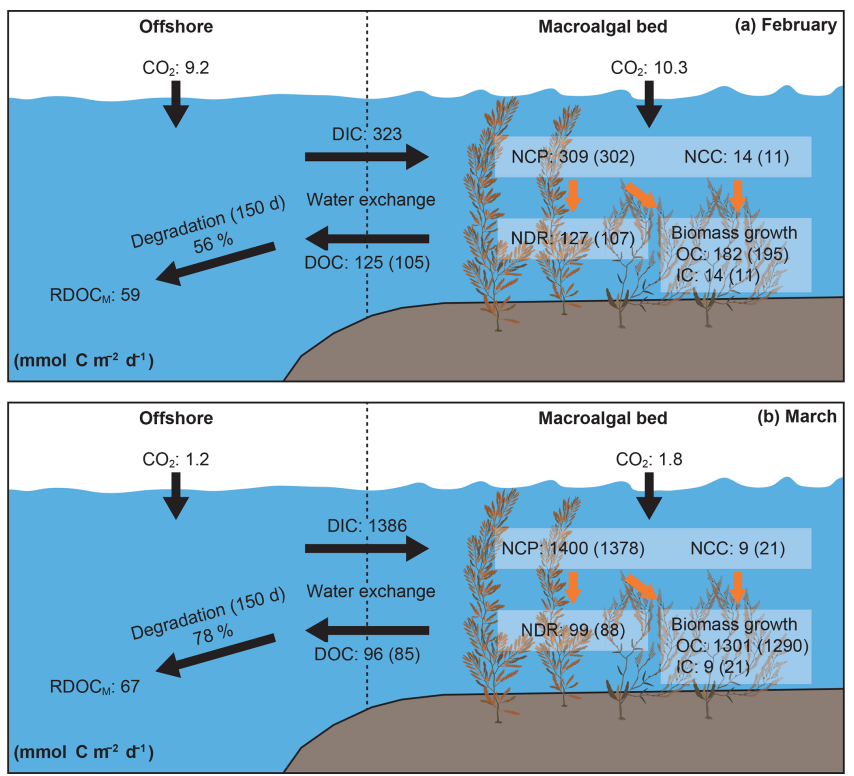

Figure 7. Carbon flows and community metabolism (NCP - net community production; NCC - net community calcification; NDR net DOC release) in the macroalgal bed. NCP, NCC, and NDR were calculated using the results of field-bag experiments (details are available in Table S1). The carbon flows due solely to macroalgae are shown in parentheses. Biomass growth in terms of organic carbon (OC) was calculated by subtracting NDR from NCP. Biomass growth in terms of inorganic carbon (IC) was the same as NCC. DIC and DOC flows via water exchange were estimated by massbalance modeling (details are available in Table 3). Community metabolism, biomass growth, and DOC outflow indicate the sum of macroalgal and planktonic carbon flows. Carbon fluxes were calculated in units of millimoles per square meter of the surface area of the macroalgal bed per day. $\mathrm{RDOC}_{\mathrm{M}}$ indicates refractory DOC released by macroalgae.

change during the day. The high rate of water exchange reduced the difference in $\mathrm{FCO}_{2}$ between the inside and outside of the macroalgal beds (Fig. 7). Conversely, water characterized by low DIC and $f \mathrm{CO}_{2}$ values was efficiently exported from the macroalgal bed to the surrounding water (Fig. 7). Our findings therefore suggested that macroalgal beds can create areas of adjacent water that serve as $\mathrm{CO}_{2}$ sinks. Previous studies have proposed that a canopy of the kelp genus Macrocystis dampens water exchange (Rosman et al., 2007), and the residence time of water within kelp beds can reach several days (Jackson and Winant, 1983; Delille et al., 2009). In contrast, the exposed side of a kelp bed is very much affected by the advection of offshore water (Koweek et al., 2017). Water exchange rates are affected by the surface area of beds, canopy development, topography, and hydrological conditions.

The seasonality of the growth of macroalgae regulates the seasonal variations in carbonate chemistry and sink-source behavior (Delille et al., 2009; Koweek et al., 2017). Annual 
fluctuations of the surface area of kelp beds affect interannual variations in air-water $\mathrm{CO}_{2}$ fluxes in adjacent water bodies (Ikawa and Oechel, 2015). In the present study, we focused on how daily carbon budgets were related to macroalgal metabolism and hydrological conditions during productive periods. The biomass of Sargassum algae fluctuates seasonally and increases in winter (from November to April) around the present study site (Yoshida et al., 2001). Future studies should assess the seasonal variability in carbonate chemistry in Sargassum beds.

The homogenous buffer factor $(\beta)$ is a general and helpful tool that can be used to identify the main processes that affect carbonate chemistry dynamics (e.g., Frankignoulle, 1994). Frankignoulle (1994) found the relationship $\beta=-7.02+$ $0.186 \times \% \mathrm{C}_{\text {org }}$, where $\% \mathrm{C}_{\text {org }}$ is the percent change of the DIC concentration due to photosynthesis and respiration. By using this equation, we calculated the $\% \mathrm{C}_{\text {org }}$ to be $96 \%$ and $88 \%$ in February and March, respectively (Fig. 4). The results therefore indicate that $\mathrm{NCP}$ was the main regulator of carbonate chemistry, and the contribution of NCC was relatively small. This conclusion is consistent with the results of the field-bag experiments (Table 1).

\subsection{Community metabolism in the macroalgal bed}

Macroalgal NCP values in the present study (302$1378 \mathrm{mmol} \mathrm{C} \mathrm{m}^{-2} \mathrm{~d}^{-1}$ ) were comparable to those in a subArctic kelp bed $\left(\sim 1250 \mathrm{mmol} \mathrm{C} \mathrm{m}^{-2} \mathrm{~d}^{-1}\right.$; Delille et al., 2009) and to gross primary production in a Macrocystis kelp bed in California $\left(\sim 570 \mathrm{mmol} \mathrm{C} \mathrm{m}^{-2} \mathrm{~d}^{-1}\right.$; Towle and Pearse, 1973; Jackson, 1987) and in an Ecklonia kelp bed (464 mmol C m${ }^{-2} \mathrm{~d}^{-1}$; Randall et al., 2019); they were much larger than the NCP values in a calcareous macrophyte bed (19 mmol C m${ }^{-2} \mathrm{~d}^{-1}$; Bensoussan and Gattuso, 2007), in temperate maerl beds $\left(-38 \mathrm{mmol} \mathrm{C} \mathrm{m}^{-2} \mathrm{~d}^{-1}\right.$; Martin et al., 2007), and on a coral reef dominated by green and red algae ( -112 to $61 \mathrm{mmol} \mathrm{C} \mathrm{m}^{-2} \mathrm{~d}^{-1}$; Falter et al., 2001). The suppression of macroalgal $\mathrm{R}$ by low water temperatures during the productive winter can explain the relatively high NCP values observed at our study site (Tables 1 and S1). The macroalgal NCP value during March was 4 times higher than the value during February in the present study (Table 1). Irradiance, length of the photoperiod, and growth phase collectively control the temporal variations in macroalgal NCP. In the present study, both surveys were conducted during the productive period, but the difference in the averaged biomass per individual $S$. horneri used for the field-bag experiments (February - $353 \mathrm{~g} \mathrm{WW}$; March - 260 g WW) may indicate a difference in growth phase.

The relative growth rates $\left(\% \mathrm{~d}^{-1}\right)$ of $S$. horneri were calculated to be $1.1-7.3 \% \mathrm{~d}^{-1}$ based on the ratio of growth ( $=\mathrm{NCP}-\mathrm{NDR})$ to biomass (Table S1). To calculate biomass, we assumed that the water content was $85 \%$ of the wet weight and that carbon content was $30 \%$ of the dry weight (Watanabe et al., unpublished data). These relative growth rates were comparable to estimates based on biomass changes of S. horneri (around $4 \% \mathrm{~d}^{-1}$; Gao and Hua, 1997; Choi et al., 2008) and S. muticum ( $\sim 10 \% \mathrm{~d}^{-1}$; Pedersen et al., 2005).

The estimated uncertainties of NCC and NCP derived from the measurement precision of TAlk and DIC were $\sim 13 \mathrm{mmol} \mathrm{C} \mathrm{m}^{-2} \mathrm{~d}^{-1}$ and $\sim 26 \mathrm{mmol} \mathrm{C} \mathrm{m}^{-2} \mathrm{~d}^{-1}$, respectively. These uncertainties were similar to NCC values (macroalgae - 11-21 $\mathrm{mmol} \mathrm{C}^{-2} \mathrm{~d}^{-1}$; phytoplankton $-12-3 \mathrm{mmol} \mathrm{C} \mathrm{m}^{-2} \mathrm{~d}^{-1}$ ) and phytoplankton NCP values (7$22 \mathrm{mmol} \mathrm{C} \mathrm{m}^{-2} \mathrm{~d}^{-1}$; Table 1). It is therefore difficult to discuss NCC values and phytoplankton NCP values quantitatively, but these values were substantially lower than macroalgal NCP values in this study. Increasing the incubation time in the field-bag experiments should help to reduce these uncertainties.

\subsection{Implications for the $\mathrm{CO}_{2}$ sequestration function of macroalgae}

Macroalgal beds are considered to be potential carbon-donor sites in the context of blue carbon sequestration (KrauseJensen et al., 2018). The release and subsequent export of particulate macroalgal carbon (e.g., entire thalli and fragments) via physical processes would contribute to $\mathrm{CO}_{2}$ sequestration (Krause-Jensen and Duarte, 2016; Filbee-Dexter et al., 2018; Pessarrodona et al., 2018; Kokubu et al., 2019; Pedersen et al., 2020; Fig. 2). The export of recalcitrant DOC from macroalgal beds is also anticipated to be an important pathway of $\mathrm{CO}_{2}$ sequestration (Wada and Hama, 2013; Barrón et al., 2014; Reed et al., 2015). A first-order assessment has suggested that almost $70 \%$ of global macroalgal carbon sequestration is attributable to DOC export to depths below the mixed layer (Krause-Jensen and Duarte, 2016). Our results showed that a Sargassum bed released a substantial amount of RDOC, which was rapidly exported from the habitat to the offshore. The maximum residence time of dissolved matter in the study's oceanographic basin is between 95 and $218 \mathrm{~d}$ depending on the season (Balotro et al., 2002), indicating that macroalgal RDOC can be exported to the outside of the Seto Inland Sea and to depths below the mixed layer via vertical mixing.

The decrease in $f \mathrm{CO}_{2}$ due to macroalgal DIC uptake directly controls the influx of atmospheric $\mathrm{CO}_{2}$ into macroalgal habitats and the waters surrounding them. The present study showed that the metabolism of Sargassum algae mediated the production of low-DIC and low- $f \mathrm{CO}_{2}$ water, which was rapidly exported to outside the habitat. Because macroalgae commonly inhabit rocky reefs facing the open ocean, macroalgal metabolism may affect a wide range of water bodies surrounding rocky reef habitats (e.g., Ikawa and Oechel, 2015). The $\mathrm{CO}_{2}$ sequestration function of macroalgae found in habitats where macroalgae-affected water easily diffuses offshore has been overlooked. 
Studies of the role of macroalgae in $\mathrm{CO}_{2}$ sequestration should use field observations and coupled ecologicalphysical models to assess the spatial spread and fate of DOC and low- $f \mathrm{CO}_{2}$ waters derived from macroalgal habitats (Kuwae et al., 2019; Macreadie et al., 2019). Because coastal primary producers other than macroalgae can also be a source of low- $f \mathrm{CO}_{2}$ and high-DOC waters, separately analyzing the fate of these waters would help shed light on the role of these ecosystems. Seasonal variations in oceanographic and climatic conditions regulate the transport of waters affected by macroalgae. Such studies will lead to a better understanding of the role of macroalgae in sequestering blue carbon and thereby mitigating global climate change.

\section{Conclusions}

The present study showed that macroalgal metabolism and lateral carbon flows regulated carbon budgets and air-water $\mathrm{CO}_{2}$ exchange in a temperate macroalgal bed and its surrounding water. Macroalgae took up DIC via photosynthesis and released large amounts of DOC to the offshore waters adjacent to the bed. Hydrological water exchange enhanced the lateral carbon flows and the spread of low- $f \mathrm{CO}_{2}$ and highDOC water mediated by macroalgal metabolism. Our findings suggest that macroalgal beds have the potential to create areas of adjacent water that serve as $\mathrm{CO}_{2}$ sinks. These results suggest the need for future research to assess the areal extent and fate of macroalgae-mediated low- $f \mathrm{CO}_{2}$ and high-DOC waters.

Data availability. The data set used in this study can be obtained from Zenodo (https://doi.org/10.5281/zenodo.3715876; Watanabe et al., 2020).

Supplement. The supplement related to this article is available online at: https://doi.org/10.5194/bg-17-2425-2020-supplement.

Author contributions. KW, GY, MH, YU, and TK conceived the study. KW, GY, MH, HM, and TK collected the samples. KW and $\mathrm{HM}$ conducted the laboratory analyses. KW and TK processed the data. KW and TK wrote the paper, with substantial input from the other authors.

Competing interests. The authors declare that they have no conflict of interest.

Acknowledgements. We thank Atsushi Kajita, Koji Manabe, and Shinjiro Sueyoshi for help in field observations and Naoko Umegaki, Hikaru Kimishima, and Ryoko Makino for chemical analyses. Finally, we thank Albert Pessarrodona Silvestre and
Dorte Krause-Jensen as reviewers for their useful comments that contributed to the development of the paper.

Financial support. This research has been supported by Grants-inAid for Scientific Research (KAKENHI) from the Japan Society for the Promotion of Science (grant nos. JP18H04156, 19K20500, and 19K12295).

Review statement. This paper was edited by Jean-Pierre Gattuso and reviewed by Dorte Krause-Jensen and Albert Pessarrodona Silvestre.

\section{References}

Abdullah, M. I. and Fredriksen, S.: Production, respiration and exudation of dissolved organic matter by the kelp Laminaria hyperborea along the west coast of Norway, J. Mar. Biol. Assoc. UK, 84, 887-894, https://doi.org/10.1017/S002531540401015Xh, 2004.

Arrieta, J. M., Mayol, E., Hansman, R. L., Herndl, G. J., Dittmar, T., and Duarte, C. M.: Dilution limits dissolved organic carbon utilization in the deep ocean, Science, 348, 331-333, https://doi.org/10.1126/science.1258955, 2015.

Balotro, R. S., Isobe, A., Shimizu, M., Kaneda, A., Takeuchi, T., and Takeoka, H.: Circulation and Material Transport in SuoNada during Spring and Summer, J. Oceanogr., 58, 759-773, https://doi.org/10.1023/A:1022858710221, 2002.

Barrón, C., Apostolaki, E. T., and Duarte, C. M.: Dissolved organic carbon fluxes by seagrass meadows and macroalgal beds, Front. Mar. Sci., 1, 42, https://doi.org/10.3389/fmars.2014.00042, 2014.

Bauer, J. E. and Bianchi, T. S.: Dissolved Organic Carbon Cycling and Transformation, in: Treatise on Estuarine and Coastal Science, edited by: Wolanski, E. and McLusky, D. S., Academic Press, Sam Diego, CA, USA, 7-67, https://doi.org/10.1016/B978-0-12-374711-2.00502-7, 2011.

Bauer, J. E. and Druffel, E. R.: Ocean margins as a significant source of organic matter to the deep open ocean, Nature, 92, 482-485, https://doi.org/10.1038/33122, 1998.

Bensoussan, N. and Gattuso, J.-P.: Community primary production and calcification in a NW Mediterranean ecosystem dominated by calcareous macroalgae, Mar. Ecol. Progr. Ser., 334, 37-45, https://doi.org/10.3354/meps334037, 2007.

Chen, W. and Wangersky, P. J.: Rates of microbial degradation of dissolved organic carbon from phytoplankton cultures, J. Plankton Res., 18, 1521-1533, https://doi.org/10.1093/plankt/18.9.1521, 1996.

Choi, H. G., Lee, K. H., Yoo, H. I., Kang, P. J., Kim, Y. S., and Nam, K. W.: Physiological differences in the growth of Sargassum horneri between the germling and adult stages, J. Appl. Phycol., 20, 729-735, https://doi.org/10.1007/s10811-007-9281-5, 2008.

Delille, B., Dellile, D., Fiala, M., Prevost, C., and Frankignoulle. M.: Seasonal changes of $p \mathrm{CO}_{2}$ over a subantarctic Macrocystis kelp bed, Polar Biol., 23, 706-716, https://doi.org/10.1007/s003000000142, 2000. 
Delille, B., Borges A. V., and Delille, D.: Influence of giant kelp beds (Macrocystis pyrifera) on diel cycles of $p \mathrm{CO}_{2}$ and DIC in the Sub-Antarctic coastal area, Estuar. Coast. Shelf Sci., 81, 114122, https://doi.org/10.1016/j.ecss.2008.10.004, 2009.

Duarte, C. M.: Submerged aquatic vegetation in relation to different nutrient regimes, Ophelia, 41, 87-112, https://doi.org/10.1080/00785236.1995.10422039, 1995.

Duarte, C. M.: Reviews and syntheses: Hidden forests, the role of vegetated coastal habitats in the ocean carbon budget, Biogeosciences, 14, 301-310, https://doi.org/10.5194/bg-14-301-2017, 2017.

Duarte, C. M. and Krause-Jensen, D.: Export from Seagrass Meadows Contributes to Marine Carbon Sequestration, Front. Mar. Sci., 4, 13, https://doi.org/10.3389/fmars.2017.00013, 2017.

Duarte, C. M. and Krause-Jensen, D.: Greenland Tidal Pools as Hot Spots for Ecosystem Metabolism and Calcification, Estuar. Coast., 41, 1314-1321, https://doi.org/10.1007/s12237018-0368-9, 2018.

Duarte, C. M., Losada, I. J., Hendriks, I. E., Mazarrasa, I., and Marbà, N.: The role of coastal plant communities for climate change mitigation and adaptation, Nat. Clim. Change, 3, 961968, https://doi.org/10.1038/nclimate1970, 2013.

Falter, J. L., Atkinson, M. J., and Langdon, C.: Productionrespiration relationships at different timescales within the Biosphere 2 coral reef biome, Limnol. Oceanogr., 46, 1653-1660, https://doi.org/10.4319/lo.2001.46.7.1653, 2001.

Filbee-Dexter, K., Wernberg, T., Norderhaug, K. M., RamirezLlodra, E., and Pedersen, M. F.: Movement of pulsed resource subsidies from kelp forests to deep fjords, Oecologia, 187, 291304, https://doi.org/10.1007/s00442-018-4121-7, 2018.

Frankignoulle, M.: A complete set of buffer factors for acid/base $\mathrm{CO}_{2}$ system in seawater, J. Mar. Syst., 5, 111-118, https://doi.org/10.1016/0924-7963(94)90026-4, 1994.

Fulton, C. J., Abesamis, R. A., Berkström, C., Depczynski, M., Graham, N. A. J., Holmes, T. H., Kulbicki, M., Noble, M. M., Radford, B. T., Tano, S., Tinkler, P., Wernberg, T., and Wilson, S. K.: Form and function of tropical macroalgal reefs in the Anthropocene, Funct. Ecol., 33, 989-999, https://doi.org/10.1111/13652435.13282, 2019.

Gao, K. and Hua, W.: In situ growth rates of Sargassum horneri (Fucales, Phaeophyta), Phycol. Res., 45, 55-57, https://doi.org/10.1111/j.1440-1835.1997.tb00062.x, 1997.

Hama, T., Yanagi, K., and Hama, J.: Decrease in molecular weight of photosynthetic products of marine phytoplankton during early diagenesis, Limnol. Oceanogr., 49, 471-481, https://doi.org/10.4319/lo.2004.49.2.0471, 2004.

Hansell, D. A. and Carlson, C. A. (Eds.): Biogeochemistry of Marine Dissolved Organic Matter, Academic Press, San Diego, CA, USA, 712 pp., https://doi.org/10.1016/C2012-0-02714-7, 2014.

Ikawa, H. and Oechel, W. C.: Temporal variations in air-sea $\mathrm{CO}_{2}$ exchange near large kelp beds near San Diego, California, J. Geophys. Res.-Ocean., 120, 50-63, https://doi.org/10.1002/2014JC010229, 2015.

Jackson, G. A.: Modelling the growth and harvest yield of the giant kelp Macrocystis pyrifera, Mar. Biol., 95, 611-624, https://doi.org/10.1007/BF00393105, 1987.

Jackson, G. A. and Winant, C. D.: Effect of a kelp forest on coastal currents, Cont. Shelf Res., 2, 75-80, https://doi.org/10.1016/0278-4343(83)90023-7, 1983.
Jiang, Z., Fang, J., Mao, Y., Han, T., and Wang, G.: Influence of Seaweed Aquaculture on Marine Inorganic Carbon Dynamics and Sea-air $\mathrm{CO}_{2}$ Flux, J. World Aquacul. Soc., 44, 133-140, https://doi.org/10.1111/jwas.12000, 2013.

Kamiya, M., Nishio, T., Yokoyama, A., Yatsuya, K., Nishigaki, T., Yoshikawa, S., and Ohki, K.: Seasonal variation of phlorotannin in sargassacean species from the coast of the Sea of Japan, Phycol. Res., 58, 53-61, https://doi.org/10.1111/j.14401835.2009.00558.x, 2010.

Kirchman, D. L., Suzuki, Y., Garside, C., and Ducklow, H. W.: High turnover rates of dissolved organic carbon during a spring phytoplankton bloom, Nature, 352, 612-614, https://doi.org/10.1038/352612a0, 1991.

Kokubu, Y., Rothäusler, E., Filippi, J.-B., Durieux, E. D. H., and Komatsu, T.: Revealing the deposition of macrophytes transported offshore: Evidence of their long-distance dispersal and seasonal aggregation to the deep sea, Sci. Rep., 9, 4331, https://doi.org/10.1038/s41598-019-39982-w, 2019.

Kondo, J.: Atmosphere Science near the Ground Surface, University of Tokyo Press, Tokyo, Japan, 336 pp., 2000.

Koweek, D. A., Nickols, K. J., Leary, P. R., Litvin, S. Y., Bell, T. W., Luthin, T., Lummis, S., Mucciarone, D. A., and Dunbar, R. B.: A year in the life of a central California kelp forest: physical and biological insights into biogeochemical variability, Biogeosciences, 14, 31-44, https://doi.org/10.5194/bg-14-31-2017, 2017.

Krause-Jensen, D. and Duarte, C. M.: Substantial role of macroalgae in marine carbon sequestration, Nat. Geosci., 9, 737-742, https://doi.org/10.1038/ngeo2790, 2016.

Krause-Jensen, D., Duarte, C. M., Hendriks, I. E., Meire, L., Blicher, M. E., Marbà, N., and Sejr, M. K.: Macroalgae contribute to nested mosaics of $\mathrm{pH}$ variability in a subarctic fjord, Biogeosciences, 12, 4895-4911, https://doi.org/10.5194/bg-124895-2015, 2015.

Krause-Jensen, D., Marbà, N., Sanz-Martin, M., Hendriks, I. E., Thyrring, J., Carstensen, J., Sejr, M. K., and Duarte, C. M.: Long photoperiods sustain high $\mathrm{pH}$ in Arctic kelp forests, Sci. Adv., 2, e1501938, https://doi.org/10.1126/sciadv.1501938, 2016.

Krause-Jensen, D., Lavery, P., Serrano, O., Marbà, N., Masque, P., and Duarte, C. M.: Sequestration of macroalgal carbon: the elephant in the Blue Carbon room, Biol. Lett., 14, 20180236, https://doi.org/10.1098/rsbl.2018.0236, 2018.

Kubo, A., Yamamoto-Kawai, M., and Kanda, J.: Seasonal variations in concentration and lability of dissolved organic carbon in Tokyo Bay, Biogeosciences, 12, 269-279, https://doi.org/10.5194/bg-12-269-2015, 2015.

Kuwae, T., Kanda, J., Kubo, A., Nakajima, F., Ogawa, H., Sohma, A., and Suzumura, M.: $\mathrm{CO}_{2}$ Uptake in the Shallow Coastal Ecosystems Affected by Anthropogenic Impacts, in: Blue Carbon in Shallow Coastal Ecosystems: Carbon Dynamics, Policy, and Implementation, edited by: Kuwae, T. and Hori, M., Springer, Singapore, 295-319, https://doi.org/10.1007/978-98113-1295-3_11, 2019.

Lewis, E. and Wallace, D. W. R.: Program Developed for $\mathrm{CO}_{2}$ System Calculations, ORNL/CDIAC-105. Carbon Dioxide Information Analysis Center, Oak Ridge National Laboratory, U.S. Department of Energy, Oak Ridge, TN, 1998.

Lønborg, C. and Álvarez-Salgado, X. A.: Recycling versus export of bioavailable dissolved organic matter in the coastal ocean and ef- 
ficiency of the continental shelf pump, Global Biogeochem. Cy., 26, GB3018, https://doi.org/10.1029/2012GB004353, 2012.

Macreadie, P. I., Anton, A., Raven, J. A., Beaumont, N., Connolly, R. M., Friess, D. A., Kelleway, J. J., Kennedy, H., Kuwae, T., Lavery, P. S., Lovelock, C. E., Smale, D. A., Apostolaki, E. T., Atwood, T. B., Baldock, J., Bianchi, T. S., Chmura, G. L., Eyre, B. D., Fourqurean, J. W., Hall-Spencer, J. M., Huxham, M., Hendriks, I. E., Krause-Jensen, D., Laffoley, D., Luisetti, T., Marbà, N., Masque, P., McGlathery, K. J., Megonigal, J. P., Murdiyarso, D., Russell, B. D., Santos, R., Serrano, O., Silliman, B. R., Watanabe, K., and Duarte, C. M.: The future of Blue Carbon science, Nat. Comm., 10, 3998, https://doi.org/10.1038/s41467019-11693-w, 2019.

Maher, D. T. and Eyre, B. D.: Benthic fluxes of dissolved organic carbon in three temperate Australian estuaries: Implications for global estimates of benthic DOC fluxes, J. Geophys. Res.Biogeo., 115, G04039, https://doi.org/10.1029/2010JG001433, 2010.

Martin, S., Clavier, J., Chauvaud, L., and Thouzeau, G.: Community metabolism in temperate maerl beds, I. Carbon and carbonate fluxes, Mar. Ecol. Prog. Ser., 335, 19-29, https://doi.org/10.3354/meps335019, 2007.

McGillis, W. R., Edson, J. B., Ware, J. D., Dacey, J. W. H., Hare, J. E., Fairall, C. W., and Wanninkhof, R.: Carbon dioxide flux techniques performed during GasEx-98., Mar. Chem., 75, 267280, https://doi.org/10.1016/S0304-4203(01)00042-1, 2001.

Mcleod, E., Chmura, G. L., Bouillon, S., Salm, R., Björk, M., Duarte, C. M., Lovelock, C. E., Schlesinger, W. H., and Silliman, B. R.: A blueprint for blue carbon: toward an improved understanding of the role of vegetated coastal habitats in sequestering $\mathrm{CO}_{2}$, Front. Ecol. Environ., 9, 552-560, https://doi.org/10.1890/110004, 2011.

Middelboe, A. L. and Hansen, P. J.: High $\mathrm{pH}$ in shallow-water macroalgal habitats, Mar. Ecol. Progr. Ser., 338, 107-117, https://doi.org/10.3354/meps338107, 2007.

Miyajima T. and Hamaguchi M.: Carbon Sequestration in Sediment as an Ecosystem Function of Seagrass Meadows, in: Blue Carbon in Shallow Coastal Ecosystems: Carbon Dynamics, Policy, and Implementation, edited by: Kuwae, T. and Hori, M., Springer, Singapore, 33-71, https://doi.org/10.1007/978-981-131295-3_2, 2019.

Nellemann, C., Corcoran, E., Duarte, C. M., Valdés, L., De Young, C., Fonseca, L., and Grimsditch, G.: Blue carbon. A rapid response assessment, United Nations Environmental Programme, Arendal, Norway, 2009.

Ogawa, H., Fukuda, R., and Koike, I.: Vertical distributions of dissolved organic carbon and nitrogen in the Southern Ocean, DeepSea Res. Pt. I, 46, 1809-1826, https://doi.org/10.1016/S09670637(99)00027-8, 1999.

Ogawa, H., Amagai, Y., Koike, I., Kaiser, K., and Benner, R.: Production of Refractory Dissolved Organic Matter by Bacteria, Science, 292, 917-920, https://doi.org/10.1126/science.1057627, 2001.

Pedersen, M. F., Stæhr, P. A., Wernberg, T., and Thomsen, M. S.: Biomass dynamics of exotic Sargassum muticum and native Halidrys siliquosa in Limfjorden, Denmark - Implications of species replacements on turnover rates, Aquat. Bot., 83, 31-47, https://doi.org/10.1016/j.aquabot.2005.05.004, 2005.
Pedersen, M. F., Filbee-Dexter, K., Norderhaug, K. M., Fredriksen, S., Frisk, N. L., Fagerli, C. W., and Wernberg, T.: Detrital carbon production and export in high latitude kelp forests, Oecologia, 192, 22-239, https://doi.org/10.1007/s00442-019-04573-z, 2020.

Pessarrodona, A., Moore, P. J., Sayer, M. D. J., and Smale, D. A.: Carbon assimilation and transfer through kelp forests in the NE Atlantic is diminished under a warmer ocean climate, Glob. Change Biol., 24, 4386-4398, https://doi.org/10.1111/gcb.14303, 2018.

Pfister, C. A., Altabet, M. A., and Weigel, B. L.: Kelp beds and their local effects on seawater chemistry, productivity, and microbial communities, Ecology, 100, e02798, https://doi.org/10.1002/ecy.2798, 2019.

Powers, L. C., Hertkorn, N., McDonald, N., Schmitt-Kopplin, P., Del Vecchio, R., Blough, N. V., and Gonsior, M.: Sargassum sp. act as a Large Regional Source of Marine Dissolved Organic Carbon and Polyphenols, Global Biogeochem. Cy., 33, 1423-1439, https://doi.org/10.1029/2019GB006225, 2019.

Queirós, A. M., Stephens, N., Widdicombe, S., Tait, K., McCoy, S. J., Ingels, J., Rühl, S., Airs, R., Beesley, A., Carnovale, G., Cazenave, P., Dashfield, S., Hua, E., Jones, M., Lindeque, P., McNeill, C. L., Nunes, J., Parry, H., Pascoe, C., Widdicombe, C., Smyth, T., Atkinson, A., Krause-Jensen, D., and Somerfield, P. J.: Connected macroalgal-sediment systems: blue carbon and food webs in the deep coastal ocean, Ecol. Monogr., 89, e01366, https://doi.org/10.1002/ecm.1366, 2019.

R Core Team: R: A language and environment for statistical computing, R Foundation for Statistical Computing, Vienna, Austria, available at: https://www.R-project.org/ (last access: 24 March 2020), 2019.

Randall, J., Wotherspoon, S., Ross, J., Hermand, J. P., and Johnson, C. R.: An in situ study of production from diel oxygen modelling, oxygen exchange, and electron transport rate in the kelp Ecklonia radiate, Mar. Ecol. Prog. Ser., 615, 51-65, https://doi.org/10.3354/meps12919, 2019.

Raven, J.: Blue carbon: past, present and future, with emphasis on macroalgae, Biol. Lett., 14, 20180336, https://doi.org/10.1098/rsbl.2018.03363, 2018.

Reed, D. C., Carlson, C. A., Halewood, E. R., Nelson, J. C., Harrer, S. L., Rassweiler, A., and Miller, R. J.: Patterns and controls of reef-scale production of dissolved organic carbon by giant kelp Macrocystis pyrifera, Limnol. Oceanogr., 60, 1996-2008, https://doi.org/10.1002/lno.10154, 2015.

Rosman, J. H., Koseff, J. R., Monismith, S. G., and Grover, J.: A field investigation into the effects of a kelp forest (Macrocystis pyrifera) on coastal hydrodynamics and transport, J. Geophys. Res.-Ocean., 112, C02016, https://doi.org/10.1029/2005JC003430, 2007.

Smith, S. V.: Marine macrophytes as a global carbon sink, Science, 211, 838-840, https://doi.org/10.1126/science.211.4484.838, 1981.

Steinberg, P. D.: Biogeographical variation in brown algal polyphenolics and other secondary metabolites: comparison between temperate Australasia and North America, Oecologia, 78, 37382, https://doi.org/10.1007/BF00379112, 1989.

Swanson, A. K. and Druehl, L. D.: Induction, exudation and the UV protective role of kelp phlorotannins, Aquat. Bot., 73, 241-253, https://doi.org/10.1016/S0304-3770(02)00035-9, 2002. 
Tokoro, T., Hosokawa, S., Miyoshi, E., Tada, K., Watanabe, K., Montani, S., Kayanne, H., and Kuwae, T.: Net uptake of atmospheric $\mathrm{CO}_{2}$ by coastal submerged aquatic vegetation, Glob. Change Biol., 20, 1873-1884, https://doi.org/10.1111/gcb.12543, 2014.

Tokoro, T., Watanabe, K., Tada, K., and Kuwae, T.: Air-Water $\mathrm{CO}_{2}$ Flux in Shallow Coastal Waters: Theory, Methods, and Empirical Studies, in: Blue Carbon in Shallow Coastal Ecosystems: Carbon Dynamics, Policy, and Implementation, edited by: Kuwae, T. and Hori, M., Springer, Singapore, 153-184, https://doi.org/10.1007/978-981-13-1295-3_6, 2019.

Towle, D. W. and Pearse, J. S.: Production of the giant kelp, Macrocystis, by in situ incorporation of ${ }^{14} \mathrm{C}$ in polyethylene bags, Limnol. Oceanogr., 18, 155-159, https://doi.org/10.4319/lo.1973.18.1.0155, 1973.

Trevathan-Tackett, S. M., Kelleway, J., Macreadie, P. I., Beardall, J., Ralph, P., and Bellgrove, A.: Comparison of marine macrophytes for their contributions to blue carbon sequestration, Ecology, 96, 3043-3057, https://doi.org/10.1890/15-0149.1, 2015.

Trevathan-Tackett, S. M., Jeffries, T. C., Macreadie, P. I., Manojlovic, B., and Ralph, P.: Long-term decomposition captures key steps in microbial breakdown of seagrass litter, Sci. Total Environ., 705, 135806, https://doi.org/10.1016/j.scitotenv.2019.135806, 2020.

Wada, S. and Hama, T.: The contribution of macroalgae to the coastal dissolved organic matter pool, Estuar. Coast. Shelf Sci., 129, 77-85, https://doi.org/10.1016/j.ecss.2013.06.007, 2013.

Wada, S., Aoki, M. N., Tsuchiya, Y., Sato, T., Shinagawa, H., and Hama, T.: Quantitative and qualitative analyses of dissolved organic matter released from Ecklonia cava Kjellman, in Oura Bay, Shimoda, Izu Peninsula, Japan, J. Exp. Mar. Biol. Ecol., 349, 344-358, https://doi.org/10.1016/j.jembe.2007.05.024, 2007.

Wada, S., Aoki. M. N., Mikami, A., Komatsu, T., Tsuchiya, Y., Sato, T., Shinagawa, H., and Hama, T.: Bioavailability of macroalgal dissolved organic matter in seawater, Mar. Ecol. Prog. Ser., 370, 33-44, https://doi.org/10.3354/meps07645, 2008.
Wada, S., Omori, Y., Kayamyo, Y., Tashiro, Y., and Hama, T.: Photoreactivity of dissolved organic matter from macroalgae, Reg. Stud. Mar. Sci., 2, 12-18, https://doi.org/10.1016/j.rsma.2015.08.018, 2015.

Wahl, M., Schneider Covachã, S., Saderne, V., Hiebenthal, C., Müller, J. D., Pansch, C., and Sawall, Y.: Macroalgae may mitigate ocean acidification effects on mussel calcification by increasing $\mathrm{pH}$ and its fluctuations, Limnol. Oceanogr., 63, 3-21, https://doi.org/10.1002/lno.10608, 2018.

Wanninkhof, R.: Relationship between wind-speed and gasexchange over the ocean, J. Geophys. Res.-Ocean., 97, 73737382, https://doi.org/10.1029/92JC00188, 1992.

Watanabe, K. and Kuwae, T.: How organic carbon derived from multiple sources contributes to carbon sequestration processes in a shallow coastal system?, Glob. Change Biol., 21, 2612-2623, https://doi.org/10.1111/gcb.12924, 2015.

Watanabe, K., Yoshida, G., Hori, M., Umezawa, Y., Moki, H., and Kuwae, T.: Dataset for the article entitled "Macroalgal metabolism and lateral carbon flows can create significant carbon sinks", Zenodo, https://doi.org/10.5281/zenodo.3715876, 2020.

Weiss, R. F.: Carbon dioxide in water and seawater: the solubility of a non-ideal gas, Mar. Chem., 2, 203-215, https://doi.org/10.1016/0304-4203(74)90015-2, 1974.

Yoshida, G., Yoshikawa, K., and Terawaki, T.: Growth and maturation of two populations of Sargassum horneri (Fucales, Phaeophyta) in Hiroshima Bay, the Seto Inland Sea, Fish. Sci., 67, 1023-1029, https://doi.org/10.1046/j.1444-2906.2001.00357.x, 2001.

Yoshida, G., Hori, M., Shimabukuro, H., Hamaoka, H., Onitsuka, T., Hasegawa, N., Muraoka, D., Yatsuya, K., Watanabe, K., and Nakaoka, M.: Carbon Sequestration by Seagrass and Macroalgae in Japan: Estimates and Future Needs, in: Blue Carbon in Shallow Coastal Ecosystems: Carbon Dynamics, Policy, and Implementation, edited by: Kuwae, T. and Hori, M., Springer, Singapore, 101-127, https://doi.org/10.1007/978-981-13-1295-3_4, 2019.

Zeebe, R. E. and Wolf-Gladrow, D.: $\mathrm{CO}_{2}$ in Seawater: Equilibrium, Kinetics, Isotopes, Elsevier, Amsterdam, Netherlands, 2001. 